\title{
Europeans at the Dutch Consular Court
}

\author{
$1 \quad$ Belonging to a European Trade Nation Abroad
}

\subsection{Forum Rei and a Clash of Laws}

Because the consular court sentenced on the basis of the merchants' style, it was equipped to adjudicate disputes that involved fellow European traders as well as Ottomans. To avoid confusion or controversy over jurisdiction, the European merchants in the Levant relied on forum rei. This was a legal custom of that came out of Roman law and was usually the default principle that settled jurisdiction. It was part of ius commune and essentially meant that a dispute between litigants falling under different jurisdictions was adjudicated at the court under whose jurisdiction the defendant fell. By the middle of the eighteenth century, it already had a long tradition in Europe of adjudicating disputes that involved foreign merchants or traders coming from different localities. The United Provinces also made use of the principle, which had been codified in Burgundian law. ${ }^{1}$ For forum rei to work in the Levant, however, it needed to be embedded in the Ottoman context. This happened in 1740, when the French received a renewed and very extensive set of capitulations, and forum rei became an officially Ottoman-sanctioned solution for determining which European consular court was to adjudicate a dispute - at a time when it had been in use for intra-European litigation for years. ${ }^{2}$

It seems that forum rei was generally accepted amongst litigants, even if it meant that a trader who felt his sentence had been unjust had to appeal at a court that could be far away. The general acceptance of this legal custom in the merchant community had not come about without some discussion and controversy, and at times, forum rei was challenged by diplomats who tried to bend the practice of law in favour of their subjects. Six months after the inclusion of the forum rei principle in the French capitulations, for instance, the Dutch ambassador in Istanbul, Cornelis Calkoen, wrote a letter to the States General about the fraudulent bankruptcy of two Venetian Jewish merchants. ${ }^{3}$ Calkoen complained that the Venetian ambassador had sequestered goods

1 Decker, Het Roomsch Hollandsch recht, 2: pp. 353-354.

2 Van den Boogert, The capitulations, p. 36. See p. 86.

3 For an analysis of bankruptcy in the early modern Ottoman context, see van den Boogert, The capitulations, pp. 207-262. 
that had come from Holland, and had consigned them to the bankrupts, without informing Calkoen. The bankrupts had been ordered to sell these goods on commission. The Dutch ambassador also complained that his Venetian colleague had issued a judgment which rendered all Dutch traders in the Ottoman Empire liable for goods that the bankrupts had sent to Holland prior to their bankruptcy and that the value of these goods would serve to reimburse Ottoman creditors. ${ }^{4}$

Additionally, the fraudulent nature of the bankruptcy was considered enough reason to guarantee that the consigned goods remained in full ownership of the Dutch merchants who had sent them. Calkoen asked that the Venetian ambassador hand over these goods to the Dutch nation and suggested negotiating a further settlement of the bankruptcy, for which specific legal procedures existed. ${ }^{5}$ He also proposed that two neutral merchants, neither Dutch nor Venetian, would be appointed jointly by himself and his Venetian colleague. Calkoen wanted the three administrators - two Venetians and a Frenchman - that had been dealing with the bankruptcy to be dismissed, as he had insufficient faith in these men 'on whose integrity much can be said'. ${ }^{6}$

The problem that had arisen was not so much a dispute on the legal custom of forum rei, nor was it caused by a different interpretation of the merchants' style; rather, it originated from the fact that bankruptcy procedures were part of national written laws. Their application in an international and intercultural context, in which existing national written laws had less use than international custom in practice, but could nonetheless be invoked in theory, made bankruptcy procedures particularly vulnerable for legalistic quarrels between consuls of different nations. ${ }^{7}$ Different localities developed their own statutes

4 Heeringa and Nanninga, Bronnen tot de geschiedenis, 3: pp. 140-142, Ambassador Cornelis Calkoen to Fagel, Istanbul, 26/11/1740. Evidence shows that, much like the European diplomats looking out for 'national' commercial interests, Ottoman courts protected the commercial interests of Ottoman subjects. Van den Boogert, The capitulations, p. 261.

5 See pp. 201-206.

6 Heeringa and Nanninga, Bronnen tot de geschiedenis, 3: pp. 140-142, Ambassador Cornelis Calkoen to Fagel, Istanbul, 26/11/1740, '[...] op wiens integriteit al veel te zeggen zoude vallen $[\ldots]$ '.

7 There is the argument that an insolvent trader's problems with creditors could be projected on the community to which the trader belonged. Avner Greif, 'History lessons. The birth of impersonal exchange: The community responsibility system and impartial justice', Journal of economic perspectives, 20:2 (2006): pp. 221-236; 'On the social foundations and historical development of institutions that facilitate impersonal exchange: From the community responsibility system to individual legal responsibility in pre-modern Europe' (June 12, 1997), sSRN working paper No. 97-o16, consulted online at https://ssrn.com/abstract $=47178$ or http:// dx.doi.org/10.2139/ssrn.47178. 
and laws on insolvency and bankruptcy, although there was a shared tradition through the medieval spreading of northern Italian bankruptcy laws by means of the system of European market fairs. ${ }^{8}$ What is striking in these laws is the severe punishment it allowed for someone unable to pay back their debts these included corporal punishment and imprisonment. ${ }^{9}$ This can be traced back to Roman law, which considered an insolvent person automatically fraudulent, according to the principle fallitus ergo fraudator ('insolvent thus a swindler').${ }^{10}$ Bankruptcy procedures came into being to settle the different debts an insolvent person had towards different creditors. Without it, creditors competed with one another trying to get some of their money back, but bankruptcy law enabled an insolvent person to file for bankruptcy and to reach a legal settlement with the creditors. ${ }^{11}$ The fact that definitions of insolvency in city regulations in Antwerp issued at the end of the sixteenth and beginning of the seventeenth century changed, not only demonstrates the continuing struggle to define exactly the legal meaning of insolvency and bankruptcy, it also puts the emergence of the idea that insolvency was not per definition fraudulent on display. ${ }^{12}$ The nature of insolvency needed to be investigated, and what did become increasingly important, then, was to look at the reputation of an insolvent trader as part of the assessment of whether he had acted bona fide or in a fraudulent manner. ${ }^{13}$

A common denominator that applied to bankruptcy procedures in most of early modern continental Europe, but not in England, was the possibility

8 Jérôme Sgard, 'Bankruptcy, fresh start and debt renegotiation in England and France (17th to 18th century), in The history of bankruptcy: Economic, social and cultural implications in early modern Europe, ed. Thomas Max Safley (London, 2013), pp. 223-235; see also Umberto Santarelli, Per la storia del fallimento delle legislazioni italiane dell'età intermedia (Padova, 1964). For the common European origins through the development of bankruptcy laws in Italy in the thirteenth and fourteenth centuries, see Joseph Kohler, Lehrbuch des Konkursrecht (Stuttgart, 1892); and Maura Fortunati, 'Note sul diritto di fiera nelle fonti giuridiche di età moderna', in Fiere e mercati nella integrazione delle economie europee secc. xiii-xvii, ed. S. Cavaciocchi (Firenze, 2001), pp. 953-966. For England, see W.J. Jones, The foundations of English bankruptcy: Statutes and commissions in the early modern period (Philadelphia, 1979).

9 Karl Gratzer, 'Introduction', in History of insolvency and bankruptcy from an international perspective, eds. Karl Gratzer and Dieter Stiefel (Södertörn, 2008), p. 6.

10 Ibid. The translation is Gratzer's.

11 Ibid.

12 Dave De ruysscher, 'Designing the limits of creditworthiness: Insolvency in Antwerp banking legislation and practice (16th-17th centuries)', Tijdschrift voor rechtsgeschiedenis, 76 (2008): pp. 317-319.

13 Ibid., pp. 318-319. 
for an insolvent trader to make private arrangements with his creditors that ensured the possibility of him continuing to do business - it made starting over again easier. ${ }^{14}$ In the United Provinces, bankruptcy procedures were regulated according to city custom, even though Charles v had issued general legislation for the Spanish Netherlands in 1531 and $1540 .{ }^{15}$ Antwerp had one of the most extensive bodies of city laws (costumen) with regard to bankruptcies, which may have been applied all over the Spanish Netherlands. They were written down in 1540, 1582 and 16o9. ${ }^{16}$ In the United Provinces, Amsterdam had the first codified bankruptcy law, based on city custom that was partially inspired by regulations in Antwerp. ${ }^{17}$ In Amsterdam, a bankrupt's estate was controlled by the aldermen, who appointed administrators (who could be creditors or other able persons). The curators made an inventory, controlled, formalised and overseen by a sheriff (schout), two aldermen, a notary and witnesses. Curators had the authority to sell goods and to consign monies to the city. The growth of the city made it impossible for the aldermen to adjudicate all disputes in Amsterdam, which led to the establishment of specialised courts during the first half of the seventeenth century. ${ }^{18}$ This included a specific court to deal with insolvencies and bankruptcy cases in 1643, the Chamber of Insolvent Estates (Desolate Boedelskamer). Later, other Dutch cities followed suit. ${ }^{19}$ The Amsterdam Chamber of Insolvent Estates operated on the basis of an ordinance issued on 6 November 1643. It was replaced by a second, updated ordinance on 2 April 1659, which was confirmed by the States of Holland and remained in vogue until 1777. A third version came into being on 30 January of

\footnotetext{
14 Sgard, 'Bankruptcy'.

15 Goswin Moll, 'De Desolate Boedelskamer te Amsterdam - Bijdrage tot de kennis van het Oud-Hollandsch failliten-recht' (unpublished $\mathrm{PhD}$ thesis, Universiteit van Amsterdam, 1879), pp. 1-2.

16 M. Aukema, 'Andere tijden. Boedelafwikkeling in de 17e en 18e eeuw', in De integere curator - Insolad jaarboek 2007, eds. M.L.S. Kalff, R. Mulder, and S.H. de Ranitz (Deventer, 2007), p. 14.

17 Although Amsterdam had developed its own legal body dealing with bankruptcy, references to Antwerp laws were still frequent during the eighteenth century. See De ruysscher, 'Antwerp commercial legislation', pp. 459-479; see also Dave De ruysscher, 'Designing the limits of creditworthiness'.

18 See pp. 116-118.

19 Aukema, 'Andere tijden', pp. 15-16. This was part of the same specialization movement that also led to the development of the maritime court in the 1640s. For a look at this court and its functioning through a case study, see Maurits den Hollander and Remko J. Mooi, 'Protecting the foreign creditor - International insolvency in early modern Amsterdam and Frankfurt am Main', TSEG/Low Countries journal of social and economic history, 16:3-4 (2019): pp. 37-57.
} 
that year and was applied until the arrival of the French Code de Commerce in $1811 .^{20}$

When a bankruptcy was reported, a specific procedure was initiated. One or two commissioners were named, as well as the curators. The estate was sequestered, a list of creditors was made, and the commissioners summoned them to a meeting, where the debtor (or someone he gave power of attorney to) was present. ${ }^{21}$ Time was provided for the debtor and creditors to reach an agreement, according to the 1777 ordinance this amounted to four weeks during which the estate could not be touched. The deal was deposed, generally at the orphanage (burgerweeshuis), and creditors could sign it. Those who did not want to sign it were publicly asked to make a claim. ${ }^{22}$ If three-quarters of the creditors agreed on a proposed agreement, the remaining quarter had to comply with it as well. In cases where an agreement was reached, the bankrupt received full control over his estate again, at the condition that he would pay all the expenses that had arisen from his bankruptcy. ${ }^{23}$ If no deal was reached within a month, the estate became officially insolvent and was registered as such. The administrators of the bankruptcy had to provide a list of monies still in their possession, and they had to provide the commissioners with their accounts. The declaration of insolvency ended the sequester, but the condition of bankruptcy remained. The administrators were replaced by curators. ${ }^{24}$ Still, there was room for deal-making, but only if all creditors agreed, not one exception. ${ }^{25}$ Creditors were asked three times to show their claim, and then curators went to liquidate the estate. The creditors had to show a balance, to be confirmed under oath by the bankrupt person. ${ }^{26} \mathrm{~A}$ public sale was held, although furniture that was not too luxurious was allowed to be sold directly to family members. Other goods had to be sold within six weeks. After the sale, a list of sold items and profits was presented at the office of the curator. ${ }^{27}$

$20 \quad$ Ibid., p. 16.

21 For more on the sequester, mostly based on 1777 regulation, see Moll, 'De Desolate Boedelskamer', pp. 29-45.

22 Ibid., p. 57.

23 Ibid., pp. 58-59.

24 Although it was stipulated that the curators had to be the former administrators, something rarely challenged. Moll, 'De Desolate Boedelskamer', p. 68.

25 Ibid., pp. 66-67.

26 Inventory of the archive 'Desolate Boedelskamer' in the City Archive Amsterdam, pp. 4-8, consulted online at https://archief.Amsterdam/inventarissen/printversie/5072.nl.pdf.

27 This was according to Aukema, 'Andere tijden', pp. 15-16. Moll wrote that a surplus was divided pro rate between creditors who had subjected themselves to the agreement (but as he does not say when, this could be a post-1777 development). Moll, 'De Desolate Boedelskamer', p. 101. 
Later, an advertisement called upon the creditors to be present at the division of the profits. First, the 'rightly preferred creditors' ('gejustificeerde preference schuldeisers') got their money, after which the 'concurrent creditors' ('concurrente schuldeisers') followed suit. ${ }^{28}$ The privileged debts towards the preferred creditors were legal expenses, salary of curators, expenses made regarding the most recent illness of the debtor (but doctors' invoices and expenses for a funeral could be lowered by aldermen if they considered them to be too high), repair costs for ships, wages of seamen, salvage money and debts made for the purchase of masts, ropes and other shipping equipment. ${ }^{29}$

The Dutch interpretation of Roman law contained legislation on privileged debts that included women's dowries, although there were some restrictions, depending on whether it was a claim on goods or monies belonging to a commercial partnership the husband had been involved in. ${ }^{30}$ The inclusion of claims of the wives of insolvent men as privileged debts was common in most early modern European bankruptcy statutes. ${ }^{31}$ In the early modern period, there was a divide in approach towards the dowry, which was a daughter's share of her parents' inheritance, given to her at the time of her marriage; in northwestern Europe, it was more vulnerable to legal claims and insolvency issues, considering it was part of the conjugal goods. In the south, particularly in Italy, the dowry was placed in a separate fund, where it was protected from possible financial claims made on the husband; it was therefore an important instrument for transferring family fortunes from one generation to the next. ${ }^{32}$ This type of protection was part of a more general European legal tradition in

28 Inventory of the archive 'Desolate Boedelskamer', pp. 4-8.

29 Moll, 'De Desolate Boedelskamer', pp. 12-13.

30 Decker, Het Roomsch Hollandsch recht, 2: pp. 93-96. This was also part of the bankruptcy rules in Antwerp, which had a big influence on Dutch regulations. Dave De ruysscher, 'The struggle for voluntary bankruptcy and debt adjustment in Antwerp (c. 1520-c. 1550)', in Dealing with economic failures: Extrajudicial and judicial conflict regulations, ed. Margrit Schulte-Beerbühl (Frankfurt, 2016), p. 81.

31 As was, for instance, the case in Augsburg. Mark Häberlein, 'Merchants' bankruptcies, economic development and social relations in German cities during the long 16th century', in The history of bankruptcy: Economic, social and cultural implications in early modern Europe, ed. Thomas Max Safley (London, 2013), pp. 19-33.

32 Jan Luiten van Zanden and Tine De Moor, 'Mensen en economie in de Gouden Eeuw', Leidschrift, 23:2 (2008): pp. 15-26. On the situation in Italy, see Christopher F. Black, Early modern Italy: A social history (London and New York, 2001), pp. 111-115. For Spain, see Elizabeth A. Lehfeldt, 'Convents as litigants: Dowry and inheritance disputes in early-modern Spain', Journal of social history, 33:3 (200o): pp. 645-664; see also Martha C. Howell, The marriage exchange: Property, social place, and gender in cities of the Low Countries, 1300-1550 (Chicago, 1998). 
which dowries were sheltered from a number of crimes that were committed by husbands. ${ }^{33}$

The final repartition of the bankrupt's estate had to take place within eighteen months after the declaration of insolvency, but if there were any legal procedures pending on (parts of) the estate, this period could be extended. The creditors could not get their money unless they had deposited a caution in the presence of two aldermen. This was meant to make sure they would return the money they had received in case new creditors showed up with prioritised claims. The sum to be deposited differed, depending on whether they were preferred or concurrent creditors. ${ }^{34}$ The 1659 ordinance made it clear that once the goods of an insolvent estate had been sold and the profits divided, the state of insolvency ended, and the merchant was again allowed to become active in commerce without his creditors having any right to stop him..$^{35}$ It is clear that this procedure was closely linked to local usages and regulations, and bankruptcies or temporary insolvencies, although they were frequent amongst traders, were not so easily resolved in cases where international creditors were affected. It was common in most early modern European bankruptcy procedures for creditors to make a majority decision, forcing dissenters to honour it. ${ }^{36}$

One of the basic steps was to compile a list of creditors in order of importance. The category of 'privileged creditors' was (and is) culturally specific, which caused problems. ${ }^{37} \mathrm{~A}$ bankrupt could hardly be expected to pay all of his creditors back, and if these creditors fell under different jurisdictions, their political or diplomatic representatives could try to weigh in on the matter as a principle for defending the commercial interests of their respective nations. ${ }^{38}$ This problem could only be solved in two ways: either through the existence

33 Hardwick, Family business, pp. 23-26.

34 According to Moll, this rule had been put into practice by the States of Holland and West Frisia. Moll, 'De Desolate Boedelskamer', p. 110; the archival inventory mentions the Hoge Raad as responsible for this.

35 For rehabilitation, see Moll, 'De Desolate Boedelskamer', pp. 134-142, and particularly p. 142 for the comment that the ordinances of 1643 and 1659 do not contain any specific clauses on rehabilitation.

36 Sgard, 'Bankruptcy'.

37 See Max Weber, The history of commercial partnerships in the Middle Ages, trans. Lutz Kaelber (Lanham, Boulder, New York and Oxford, 2003), pp. $76-78$.

38 In their analysis of the insolvency case of Amsterdam merchant Gasparo Schellekens in 1701, Maurits den Hollander and Remko Mooi have argued that, rather than competing, there was cooperation between the Amsterdam Chamber of Insolvent Estates and the Frankfurt city council, a city in which Schellekens had creditors, and that such cooperation was not exceptional. Den Hollander and Mooi, 'Protecting the foreign creditor'. 
of legislation apt at dealing with international disputes or through the establishment of certain customs that could be used as long as they were accepted by all sides as being an international norm. In the Ottoman context, some regulations and legislation did exist that could be used to solve international disputes. The capitulations had given legal autonomy to diplomats, but this was undermined by the frequent involvement of Ottoman creditors in bankruptcy cases. This involvement warranted the greater participation of Ottoman courts, who were just as concerned with their subjects' commercial well-being as European diplomats were instructed to be with theirs. Van den Boogert has shown that bankruptcy resolution in the Ottoman context relied on Ottoman law, but his research did not address the problematic nature of bankruptcy resolution amongst Europeans in an Ottoman context. ${ }^{39}$ It seemed this was again left to customary agreements made amongst Europeans, and this could be problematic considering the importance of local bankruptcy laws, which could be irreconcilable with the various national commercial interests as defended by diplomats.

In the abovementioned argument between Ambassador Calkoen and his Venetian colleague, the former seemed convinced that the bankruptcy had been a fraudulent one, which had important legal repercussions. For Calkoen, this label of bankruptcy 'in infamia' led to the legal argument that the merchants in Holland should remain 'in plena possessione' and 'ad dispositionem' of their merchandise - rather than having it sequestered by the Venetian ambassador, whose sequester was a harsh and irregular manner of procedure. ${ }^{40}$ It is unsurprising that Calkoen called out the failure to adhere to procedure, as that was so essential in commercial litigation. But while the law was clear enough on this matter, it did not suffice to get Calkoen what he wanted, which is why he demanded the nomination of two neutral merchants to deal with the bankruptcy instead of the already appointed Venetians.

It seemed that, in the tension created by the juxtaposition of national interest and several bodies of local law, merchant custom, in the form of judgment by neutral traders, was called upon to solve the imbroglio. Rather than relying on any national law, which could surpass local regulations, but which was, according to van den Boogert, only seldomly invoked in eighteenth-century bankruptcy cases, judgment would have to come from within the merchant community and the 'universal' and rational principles of the merchants'

39 Van den Boogert, The capitulations, pp. 207-262.

40 Heeringa and Nanninga, Bronnen tot de geschiedenis, 3: pp. 140-142, Ambassador Cornelis Calkoen to Fagel, Istanbul, 26/11/1740, on p. 141, '[...] zoo harde en irreguliere wyze van procedeeren'. 
style. ${ }^{41}$ The appointment of neutral merchants was intended to avoid the unilateral pursuit of advantage, in this case not individual but national. Calkoen had to defend national interest, and in the case of a bankruptcy, it was a matter of limiting the losses of his countrymen to the greatest extent possible. The Venetian ambassador was doing the same, hence his nomination of Venetian merchants and his active efforts to lay claim on goods that were or had been in the hands of the bankrupts.

The Venetian ambassador's attempt to legally assert the financial liability of Dutch traders in Istanbul was based on an old custom, the community responsibility system. By using evidence from Flanders, England and Italy, Avner Greif has argued for the existence of a medieval system of punishment, based on the principle that all merchants belonging to a foreign trading nation could be held accountable for the actions of one merchant of that community. ${ }^{42}$ It was one of the possibilities motivating a foreign trading community to prevent their members from cheating and a substitute for the absence of strong, neutral and centralised courts, and one could consider this a form of exogenous motivation. This co-existed - and was intertwined - with internal forms of control and retribution, in which the community itself punished a merchant for fraudulent behaviour. Perhaps the most popular measure was excommunication, a measure that seems to have been most effective in places where particular foreign communities did not interact all that much with host society. ${ }^{43}$

Endogenous forms of punishment relying on social ostracism do not necessarily need a legal justification - as long as there is a sense of being a separate community, community leaders, legally sanctioned by the host society or not, can punish cheaters. The collective responsibility system, however, was more closely tied to legal principles. Sheilagh Ogilvie has shown that collective punishment was a medieval custom that was only invoked when a legal claim on an individual had failed. The custom had developed in response to the problem of debt collection, and following forum rei, a creditor first had to seek justice against the debtor in the court under which jurisdiction the latter fell. Only when that failed, the creditor could seek recourse to collective responsibility.

41 Van den Boogert's remark on the absence of any reference to national law can be found in The capitulations, p. 259.

42 Greif, 'History lessons'; and 'On the social foundations'; see also Ogilvie, Institutions and European trade, pp. 272-276; and Gelderblom, Cities of commerce, p. 8.

43 Trivellato, Familiarity of strangers, pp. 165-167. An important example she gives is that of the Jewish diaspora - excommunication worked less as incentive in Amsterdam, where the Jewish community was fairly well-accepted, than in, for instance, Hamburg; see also Aslanian, From the Indian Ocean, pp. 171-174. 
In that sense, 'a collective reprisal was formulated as a punishment not against a community of merchants but against a legal system that had failed to render justice. ${ }^{44}$ It is a crucial nuance to Greif's theory on collective responsibility which gave too much credit to collective punishment as an autonomous institution supporting long-distance trade; Ogilvie manages convincingly to place collective punishment firmly within a formal legal context, rather than as an informal alternative to it - and individual responsibility remained an important component of it. ${ }^{45}$

While collective punishment helped to motivate a community to exercise pressure on their members to not commit fraud, it was also an important legal connection between foreign trading community and host society - particularly as it was common for foreign trading communities to be granted a degree of legal autonomy. Over time, collective responsibility in this strict sense of collective punishment disappeared, although remnants of the old custom for holding communities accountable for individual members' behaviour endured in certain contexts. Particularly in environments in which social ties such as kinship or religious affiliation were important as determinants for business, excommunication could be an important deterrent. Forms of punishment that relied on social ostracism have persisted into the twentieth century in specific closed environments such as New York's diamond district. ${ }^{46}$

The attempts of the Venetian ambassador in the bankruptcy case discussed above also demonstrate the persistence of some ideas on collective responsibility, although it was hardly surprising that these stirred controversy. The Venetian ambassador had not used old custom simply to obtain satisfaction from an offender who happened to belong to another nation but to defend the national interests of Venetian subjects in a matter of fraudulent bankruptcy. His Dutch colleague tried to do the same, and he defended the interests of his subjects. The matter pitted two communities against one another, so the recourse sought through the community responsibility system is not so strange in itself. What made it peculiar is that it had been out of use for so long. There is no information on how the issue was resolved, as the only further comment came from Calkoen's secretary in a letter to his brother, mentioning that the bankrupts had fled. ${ }^{47}$

44 Ogilvie, Institutions and European trade, p. 274.

45 Ibid., pp. 272 and 276.

46 Lisa Bernstein, 'Opting out of the legal system: Extralegal contractual relations in the diamond industry', Journal of legal studies, 21:1 (1992): pp. 115-157.

47 Heeringa and Nanninga, Bronnen tot de geschiedenis, 3: pp. 143-144, Secretary Jan Carel des Bordes to his brother, Istanbul, 30/11/1740. 


\subsection{Competition from Within: The Prussian Royal Levant Company}

National competition was a tangible element of the interaction between European communities in Izmir. The consuls of the respective nations made no secret that one of their main responsibilities was to foster national commercial interests, and while traders were not necessarily motivated to look after the interests of the state to which they belonged, if they did well, the state also did well. Through custom duties and taxes, the state ensured it received its financial share of any success its merchants had. Because these taxes had been so disputed in the past, the state, in the Dutch case the States General, introduced other measures to ensure that Dutch traders were aware they were also serving Dutch interests and not simply their own or those of their correspondents and business partners. If a merchant undertook actions that were seen as harmful to the state, the consul intervened. A good example is the treatment of the firm of Clement, van Sanen, van der Zee \& $C^{\circ}$ in the 176 os. In May 1765 , the Prussian King Frederik gave Philippe Clement and his company the exclusive rights to trade between Prussia and the Levant for twenty years. This new Prussian Royal Levant Company was financed by the issuing of shares, and Philippe Clement was to be its director general and president in Berlin, while Pieter van Sanen, already Prussian consul in Izmir, was to serve as its director general in the Levant. ${ }^{48}$ At the time, Pieter van Sanen was assessor at the Dutch consulate and thus closely involved in different matters of the consulate, particularly adjudication.

The Dutch ambassador in Istanbul, Willem Gerrit Dedel, sent letters to the States General and the States of Holland to explain the situation and ask them for advice. The problem was that Clement and van Sanen were Dutch, and as such, they would continue to enjoy Dutch protection and fall under Dutch jurisdiction. At the same time, their new Prussian functions also made them important agents in the development of an enterprise whose success would come at the expense of the Dutch, and Dedel wrote about van Sanen that 'under our protection and with his Dutch firm, he can give considerable support to his Prussian trade factory and as consul he can greatly suppress our trade'. ${ }^{9}$ If the States General did not order him otherwise, he could not take away Dutch protection from these men, particularly as it was not uncommon

48 Heeringa and Nanninga, Bronnen tot de geschiedenis, 3: pp. 494-50o, 'Octrooy van een exclusieven handel op den Levant, verleend door Frederik, koning van Pruisen, aan Philip Clement', Berlin, 17/05/1765.

49 Heeringa and Nanninga, Bronnen tot de geschiedenis, 4: p. 6, Ambassador Willem Dedel to Fagel, Istanbul, 16/og/1765, 'Onder onse bescherming en met zijn Hollandsch huis kan hij zijn Pruissise factorie merkelijk ondersteunen en als consul onze negocie zeer drukken'. 
for European trading nations to extend protection to certain groups of nonnationals. Additionally, the Prussian envoy in Istanbul had asked Dedel to accept joint Dutch-Prussian protection for these men, something the ambassador found difficult to refuse..$^{50}$ Dedel, unsure how to act, also put the question directly before the States of Holland: 'shall these people be given the opportunity to destroy our trade here, established for a long time, while being under our protection?'51

The Directorate of Levant Trade, consulted on the matter, suggested that Pieter van Sanen should be convinced to renounce his assessorship voluntarily, while the status of Clement, van Sanen, van der Zee \& $\mathrm{C}^{\circ}$ as a Dutch firm should be discussed at a later time..$^{52} \mathrm{~A}$ meeting on this topic was indeed held in Izmir in February 1766, and the consul, assessors and treasurer decided that van Sanen could no longer be assessor and that the firm of Clement, van Sanen, van der Zee \& $\mathrm{C}^{\circ}$ would not be allowed to enjoy Dutch protection any longer. Only van der Zee, who had expressed his intention to leave the partnership, could remain under Dutch protection, unless he explicitly asked for it to be removed. Van Sanen and van der Zee were both further questioned about the Prussian Royal Levant Company and their interest therein, and when they indeed confirmed as much, van Sanen was dismissed as assessor and was no longer bound by the Dutch national oath. From this time onwards, he was to be considered a foreigner, and this also applied to the payment of consular fees. ${ }^{53}$

After this, apparently, things took a turn for the worse for van Sanen, who became ill, feverish and mad, denying he wanted to be consul. Rumours spread he was locked up in a warehouse, 'roaring like an ox' that there was a fire. ${ }^{54}$ Van Sanen was succeeded as Prussian consul by his business partner van der Zee,

50 Ibid.

51 Heeringa and Nanninga, Bronnen tot de geschiedenis, 4: pp. 6-7, Ambassador Willem Dedel to the grand pensionary of Holland, Istanbul, 16/og/1765, 'Zal men die luiden geleegenheid geeven onder ons eige bescherming onze van oudsher hier gestelde koophandel te vernielen?'

52 Ibid., p. 8, Directorate of Levant Trade to Consul Daniel Jean de Hochepied, Amsterdam, 24/og/1765. This was confirmed in a meeting in Amsterdam in October 1765. Ibid., pp. 1617, 'Extra-ordinaris vergadering met de buitenleden te Amsterdam', Amsterdam, 30/10/ 1765 , when it was also decided that van Sanen could no longer attend meetings between consul, assessors and treasurer.

53 Ibid., pp. 35-36, 'Extract uyt de notulen ter gehouden bisoignes in de vergaaderinge van consul en assessooren etc. der Neederlandse natie', Izmir, o3/o2/1766. Nicolas van der Zee was not involved as director or consul. Even though he held shares in the Prussian Royal Levant Company, Dutch protection was not taken away from him.

54 As quoted from a letter written by Consul Hochepied to the States General in a footnote in Heeringa and Nanninga, Bronnen tot de geschiedenis, 4: p. 139, '[...] hij bruld als een os [...]'. 
who remained consul until 1771, when he renounced all his Prussian offices as well as his involvement in the firm of Clement, van Sanen, van der Zee \& $\mathrm{C}^{\circ}$ and asked permission to return under Dutch protection. ${ }^{55}$ It was not given to him, because he could not give sufficient assurance that he had settled all his debts. A renewed request made by van der Zee at the end of 1773 was equally denied, even if all of his creditors were paid, because the States General needed assurance he had no further business engagements with Prussian or Ottoman subjects. 56

The reasons for van der Zee's first request, as well as the refusal of the States of Holland to grant it, became clear very quickly to Daniel Jean de Hochepied, Dutch consul in Izmir. At around the time of van der Zee's first request, he turned down a petition from the Prussian envoy in Istanbul to act on his behalf in the settlement of the affairs of the house of Clement, van Sanen, van der Zee \& $\mathrm{C}^{\circ}$. Following van Sanen's onset of madness, the company had been performing poorly and was indebted to many Ottoman subjects, including several Muslims. ${ }^{57}$ The Royal Bank of Berlin had lent a good deal of money to the Prussian Royal Levant Company and withdrew their support. In March 1771, David van Lennep and William Enslie, prominent Dutch merchants, had already let the Prussian envoy in Istanbul know that, should the firm Clement, van Sanen, van der Zee \& $\mathrm{C}^{\circ}$ go bankrupt and the Royal Bank of Berlin wanted to press its claim against the firm, van Lennep and Enslie did not want to have anything to do with the affair. ${ }^{58}$

55 Ibid., pp. 153-154, Chargé d'affaires Frederik Johan Robert de Weiler to Fagel, Istanbul, 17/ 04/1771. After the death of Willem Dedel, the Dutch ambassador in Istanbul, in 1768, his secretary, Frederik Johan Robert de Weiler, was promoted to chargé d'affaires. In 1775 he was promoted to ambassadorship. Schutte, Repertorium der Nederlandse vertegenwoordigers, p. 312 .

56 Resolutien van de heeren Staaten van Holland en Westvriesland in haar edele groot mog. vergadering genoomen in den jaare 1774 (S.l., S.d.), pp. 325-326, 'Resolutie op de Missive van den Consul de Hochepied te Smirna omtrent het versoek van de geweese Pruissische Consul vander Zee, om weederom onder haar hoog mogende protectie te geraaken', 22/ 04/1774.

57 Heeringa and Nanninga, Bronnen tot de geschiedenis, 4: pp. 16o-161, Consul Daniel Jean de Hochepied to Fagel, Izmir, 20/o7/1771; and ibid., pp. 164-165, Directorate of Levant Trade to Consul Daniel Jean de Hochepied, 17/12/1771. The court case against Arnoldus Wissing, who had been responsible for the firm's affairs in a period of absence or the unavailability of all three partners, was part of this tumultuous affair; see pp. 139-144.

58 NACS, $\mathrm{N}^{\circ} 25$ ('Stukken betreffende faillissementen. Clement, van Sanen \& van der Zee, Nederlandse kooplieden te Smyrna, 1779'), 'Extrait d'une letter écrite par les soussignés [David van Lennep and William Enslie] a monsieur de Zegelin envoyé de sa majesté le roy de Prusse à la Porte ottomane', Izmir, 30/03/1771. The firm went bankrupt in 1770, and this letter was incorporated in the bankruptcy file. 
To make matters worse, Nicolas van der Zee was behind with the payments he needed to make to the Ottoman administration on behalf of Prussia. De Hochepied refused to intervene in the manner, as he thought it would be a lengthy affair, with little to win. He felt that it would harm his work on behalf of Dutch national interests - a decision he was complimented for by the Directorate of Levant Trade. ${ }^{59}$ The affair meant the end of the Prussian Royal Levant Company. ${ }^{60}$ A year later, van Sanen's Dutch wife demanded Dutch protection for herself, but it was refused to her on the grounds that it had been taken away from her husband. Dutch assistance for her would involve the Dutch trading community in the handling of the closure of the Prussian Royal Levant Company, which nobody wanted. ${ }^{61}$

Prussian involvement had ended badly for all partners of the Clement, van Sanen and van der Zee partnership, partially because of poor commercial decisions, but also partially because their decision to work on behalf of Prussia cost them Dutch institutional protection. Matters turned out to be a bit different for the man who was later seen as partially responsible for those poor choices, Arnoldus Wissing, the firm's accountant with the power of attorney enabling him to conduct business in the partnership's name. ${ }^{62} \mathrm{~A}$ compromise was reached about him. When he acted in the name of the firm of Clement, van Sanen, van der Zee \& $\mathrm{C}^{\circ}$, his actions were not protected by a Dutch status, but when he acted as his own person, he continued, as a Dutch national, to fall under Dutch protection. ${ }^{63}$ The decision was officialised in a resolution issued by the States of Holland, and part of the justification was the reasoning that if Wissing would not be allowed to enjoy Dutch protection when trading in his own name, it could harm the practice of foreign consuls who acted as Dutch consuls ad interim. The loss of protection when providing services for a firm belonging to another nation might make foreign consuls

59 Heeringa and Nanninga, Bronnen tot de geschiedenis, 4: pp. 16o-161, Consul Daniel Jean de Hochepied to Fagel, Izmir, 20/07/1771; and ibid., pp. 164-165, Directorate of Levant Trade to Consul Daniel Jean de Hochepied, 17/12/1771.

6o A few decades earlier, the Prussian Asiatic Trade Company had met with same fate. These debacles led to King Frederik's decision to forbid all Prussian investment in overseas trading companies. See Florian Schui, 'Prussia's "trans-oceanic moment": The creation of the Prussian Asiatic Trade Company in 1750', The historical journal, 49:1 (2006): pp. 143-16o.

61 Heeringa and Nanninga, Bronnen tot de geschiedenis, 4: pp. 172-173, Directorate of Levant Trade to the burgomasters of Amsterdam, 04/o9/1772.

62 See pp. 139-144.

63 Heeringa and Nanninga, Bronnen tot de geschiedenis, 4: pp. 138-139, Directorate of Levant Trade to the burgomasters of Amsterdam, Amsterdam, 21/o2/1770. 
reconsider when asked to temporary take on a consular position on behalf of the Dutch. ${ }^{64}$

It is understandable that it took time for the States General, the Directorate of Levant Trade, the consul and the ambassador to reach a decision on the status of everyone involved. While the Prussian Royal Levant Company was a clear threat to the Dutch national interests that the institutions were meant to protect, these men were Dutch, and protection could not be taken away lightly, especially as the consequences reached further than loss of political protection. In September 1765, Thomas de Vogel in Amsterdam had already instructed his son Thomas Junior to not do any more business with Philippe Clement, as it would upset their other correspondents, who were likely to brand de Vogel as a traitor to the United Provinces and its commerce, an accusation already circulating in Amsterdam's commercial circles. Earlier, Clement, van Sanen, van der Zee \& $\mathrm{C}^{\circ}$ had litigated with de Vogel in Izmir, a matter that was not considered as sufficient reason to stop doing business with one another, as both firms continued to do so. ${ }^{65}$

What made this situation different was that Philippe Clement had entered Prussian service because he had financial difficulties. The crossing of national boundaries, from the United Provinces to Prussia, was not bad per se, but having done it for personal profit was a problem. Renouncing one's nation for reasons of personal profit was usually regarded as a severe misstep and could lead to serious damage to one's reputation. ${ }^{66}$ When the pursuit of self-interest conflicted with the loyalty that was expected from merchants on the basis of reciprocity, which was part of merchant custom, a trader was attacked, and punished, for his choice. This is essentially why Clement and van Sanen were ostracised from the Dutch community for their involvement in the Prussian Royal Levant Company. It was not a matter of 'national' interest alone, it was also a matter of corroding one of the essential norms dictated by the merchants' style.

64 Resolutien van de heeren Staaten van Holland en Westvriesland in haar edele groot mog.vergadering genoomen in den jaare 1770 (S.l., S.d.), pp. 337-338. 'Resolutie op de Missive van den Consul Hochepied te Smirna, om te weeten, hoe sig te gedraagen nopens den gesubstitueerden van den Pruissischen Consul vander Zee', 10/03/1770. Consul de Hochepied had sent a letter explaining the situation on 17 January 1770.

65 See pp. 146-152.

66 Heeringa and Nanninga, Bronnen tot de geschiedenis, 4: pp. 1193-1194, Thomas de Vogel to Thomas de Vogel Junior, Amsterdam, 20/og/1765. 


\subsection{A Local European Dispute without any Dutch Involvement}

Another form of European competition was the desire of some of the more successful nations to take merchants without diplomatic representation in the Levant under their formal protection. European consuls could even become vice-consuls for other nations. Pieter van Sanen's combination of two consulships had not worked out because he had not received permission and because his actions were considered too selfish and detrimental to Dutch national interests, but this was not considered to be the case for the various vice-consulates occupied by members of the de Hochepied family in Izmir at times, they acted as representatives for the Habsburg Empire, the Grand Duchy of Tuscany, Denmark, Sweden and later also Russia, while also protecting the interests of Polish traders at certain moments. ${ }^{67}$

During Daniel Alexander de Hochepied's tenure as consul, between 1720 (initially ad interim) and 1759, the Dutch were also protecting two Genoese traders. ${ }^{68}$ It is unclear whether this stemmed from an agreement with the Genoese government or whether it was a form of individual protection. Giuseppe Copurro was a bachelor, but Gian Carlo Giera had married a Dutch woman, and in 1759, he had already lived in Izmir for twelve years. ${ }^{69}$ A relative of Gian Carlo named Giovanni Lorenzo Giera was referred to in another trial as a 'négociant Genois protégé de France', and the name comes up on a list of French merchants in Izmir in $1751{ }^{70}$ A certain Pietro Paolo Giera was said to be part of Livorno's Board of Commerce in 1717, and the Giera family can be found in Livorno in the early nineteenth century as a merchant family. ${ }^{71}$ Another Pietro Paolo Giera appears in the archives of the Chamber of Commerce in Trieste amongst the records discussing relations between the Habsburg court in Vienna and the Dutch Republic in 1784, involving letters from vice-consuls and agents, in this case de Hochepied as Austrian vice-consul and Pietro

$67 \quad$ See pp. $53^{-55}$.

68 See table 2.

69 Ibid.

70 NACs, $\mathrm{N}^{\circ} 383$ ('Paulo Poma, Grieks koopman te Smyrna, tegen Giovanni Lorenzo Giera, Toscaans koopman te Smyrna, 179o'), [Declaration of French consul Amoreux], Izmir, 29/08/1791. Michel Morineau, 'Naissance d'une domination. Marchands européens, marchands et marchés du Levant aux XVIIIe et XIXe siècles', Cahiers de la Méditerranée, 1 (1976): p. 184. The list is not without its problems, as it contains for instance the names of Fremeaux and van der Sanden, and members of those families were part of the Dutch trading community of Izmir; see table 2.

71 Alessandro Volpi, Banchieri e mercato finanziario in Toscana (1801-1860) (Firenze, 1997), p. 131; and David G. LoRomer, Merchants and reform in Livorno 1814-1868 (Berkeley, Los Angeles and Oxford, 1987), p. 83. 
Paolo Giera in Izmir as agent. ${ }^{72} \mathrm{~A}$ Memoria published in Livorno by Carolina Bartoletti, the widow of Pietro Paolo Giera, in 1818 clarifies that her husband had been Austrian consul in the Levant, as well as deputy to the legislative body in Paris and president of the commercial tribunal in Livorno. ${ }^{73} \mathrm{~A}$ number of other cases brought before the Dutch consular court involve Giera family members, such as Giuseppe and Gian Carlo Giera, Genoese merchants in Izmir (1745), Giancarlo Giera, Tuscan merchant (1792), and Jean-Laurent Giera, Tuscan merchant (1806). ${ }^{74}$ It seems the Giera family was indeed an internationally settled merchant family and had, by the time Giovanni Lorenzo Giera became a defendant in this case, established themselves in Paris, possibly also in Genoa, Livorno and Izmir.

In any case, Gian Carlo Giera fell under Dutch jurisdiction. If a plaintiff wanted to summon him in court, Giera would be judged by the Dutch consul following the principle of forum rei. It is because of this principle that the firm of Giuseppe and Gian Carlo Giera found itself as the defendant at the Dutch consular court in Izmir in 1745. The plaintiff was the French firm of Séguier Père \& Fils, also from Izmir. Jean Antoine Butini, the Swedish consul in Marseille, had shipped 120 bales of American coffee and eight bundles of cloth on the Swedish ship Resolution of the skipper Nils Svanson to Izmir and consigned it to the Giera firm. In a letter sent on 30 April 1745, Butini repeated a demand he had made three days earlier, when he asked the Giera firm to deliver the goods destined for Izmir to Séguier upon their arrival. Séguier had already received an order from Butini to sell them and to reimburse any expenses the Giera firm had made as intermediary. The plan to use the Giera firm as intermediary in the first place had come from Gian Carlo's brother and partner Giuseppe, who had freighted the ship in Marseille. He considered it a good way to avoid Mediterranean corsairs, who were considered more likely to plunder Butini's goods if they were addressed to a French firm. Butini had been trading with

72 Archivio di Stato di Trieste, Deputazione di Borsa poi Camera di Commercio e d'Industria di Trieste (1755-1921). Serie 7: Carteggio Cxxx, 'Comunicazione del C.R. governo della sostituzione, visti i rapporti tra la corte di Vienna e la Repubblica d'Olanda' (1784).

73 Carolina Bartoletti, Memoria per la signora Carolina Bartoletti vedova Giera, sacerdote sig. Luigi Cartacci suo maestro di casa e Maddalena Melani sua cameriera nella causa di preteso furto avanti la r. ruote criminale di Firenze (Livorno, 1818), p. 3.

74 NACs, $\mathrm{N}^{\circ} 317$ ('Stukken rakende het voldongen proces tusschen Seguier pere $\mathrm{x}$ fils en Giuseppe en Gio Carlo Giera, 1745'); N 396 ('Gian Carlo Giera, Toscaans koopman te Smyrna, tegen Govert Swenson, kapitein van het Nederlandse schip Clasina, 1792'); and $\mathrm{N}^{\circ} 454$ ('Jean Laurent Giera, Toscaans koopman te Smyrna, tegen Daniel Fremeaux \& Co., $\left.1806^{\prime}\right)$. 
Séguier for a long time, to his satisfaction, which is why he hoped the Giera firm would not make a problem of it. Additionally, they should exercise some caution, considering the Marseille Chamber of Commerce, in its role as controller of French Levant Trade, did not look favourably upon the consignment of goods coming from France to non-French firms in the Levant. Séguier had demanded the handover of the goods from Giera verbally, but they had refused, so Séguier turned to the competent judge, Consul Daniel Alexander de Hochepied, to obtain them. ${ }^{75}$

After the claim was registered, the Giera firm was given two days to come up with a written answer. In their reply, they claimed that Butini had given them the order to sell the goods and to purchase Angora yarn with the profits. Giera included an extract from Butini's letter from 27 April, in which the Swedish consul ordered them to receive and sell the goods and to look for some merchandise to be shipped on Svanson's vessel for the return voyage. In exchange, Butini claimed he might be able to obtain some good terms for future shipping on Swedish vessels as the consul. It must have been a tempting promise, as at the time, in the middle of the War of Austrian Succession, shipping on French vessels was dangerous, while Swedish ships were popular. ${ }^{76}$ The Giera firm argued that the new orders for Séguier had come too late, as they had already sold the goods and decided to invest in Angora yarn. ${ }^{77}$

As with most commercial disputes brought before the Dutch consul in Izmir, the problem was with the middlemen, but what set this case apart was that the Giera firm was not supposed to engage in commercial transactions but only in the shipping. They were not used as agents but rather as an instrument to avoid problems with corsairs at sea. As in almost all cases, the consul asked for a second round of declarations and gave the French firm three days to reply. Séguier addressed all the points that Giera had raised and included extracts from Butini's letters to argue that the Giera firm had abused their role to appropriate a commission that was not theirs, acting 'mal à propos and against the

75 NACs, $\mathrm{N}^{\circ} 317$, 'Request van de messrs Seguier pere $\mathrm{x}$ filz, aen haer ho: mo: consul, a di 21 Juny 1745 g'apostilleert 22 detto en aen Giuseppe x Gio Carlo Giera g'intimeert en copije gelaten', Izmir, 21/06/1745.

76 Leos Müller, 'Commerce et navigation suédois en Méditerranée à l'époque moderne (1650-1815)', Revue d'histoire maritime, 13 (2011): pp. 45-70; and his 'Swedish shipping in southern Europe and peace treaties with North African states: An economic security perspective', Historical social research/Historische Sozialforschung, 35:4 (2010): pp. 190-205.

$77 \quad$ NACs, $\mathrm{N}^{\circ} 317$, 'Antwoord van Giusepp x Gio Carlo Giera opt reqt van Seguier pater e figlio van dato den $21 \mathrm{~d}^{\circ}$ dit g'intimeert den 28 aen seguier et volgens apostil, en copije gelaten', Izmir, 25/06/1745. 
good faith of commerce. ${ }^{78}$ According to the Frenchmen, Giera had been verbally informed in Izmir by Séguier (the father) not to sell the merchandise received, as Butini's real intent had been to give the commission to the Séguier firm, and it was not the first time the Frenchmen had received commissions from Swedish merchants through an artificial intermediary intended solely to deceive corsairs. Three days after the commission order to Giera, Butini clarified that the real commissioning agents should be the Séguier firm. Giera refused to listen and quickly bartered the goods for Angora yarn. Additionally, Giuseppe Giera had been misleading, concocting a shipping plan with Butini without informing his brother in Izmir, something he easily could have done, as the Giera firm had sent a commis on Svanson's vessel who could (and should) have transmitted the message in person. Furthermore, the facts demonstrated that the Giera firm had committed a cardinal sin by not acting in Butini's interest, who had not asked for the barter transaction with the yarn. Even if the Giera firm had acted in good faith (which, according to Séguier, they clearly had not), they had acted as bad traders. It was thus a serious infraction against commercial custom, and Séguier insisted that either the goods, or their value in current money from Izmir, as valued by court-nominated experts, would be delivered to them. ${ }^{79}$

Gian Carlo Giera replied that he found the claims against his firm misleading and accused the Séguier firm of having the malicious idea to tarnish by their accusation the clarity of their true and candid motivations'. ${ }^{80}$ They did not want to reply to all of the accusations, false as they were, but left that to those familiar with the firm's 'character'.81 The Séguier firm insisted on its discourse and accused the Giera firm of manipulating things, referring back to the barter transaction the Giera firm had made so hastily but that was so disadvantageous for Butini, labelling their effort as exchanging 'a bar of gold for a bar of iron', ${ }^{82}$ The Séguier firm felt that the reason Giera had acted so speedily was to

78 NACs, $\mathrm{N}^{\circ} 317$, 'Replicq van Seguier pere $\mathrm{x}$ filz opt antw:t van giusepp x Gio Carlo Giera van den 25 tevooren geapostileert den 6 julij en hetzelve g'intimeert, en copije gelaten', Izmir, $30 / 06 / 1745$, '[...] mal a propoz et contre la bonne foy du commerce [...]'.

79 Ibid.

8o NACS, $\mathrm{N}^{\circ} 317$, 'Repliq van Giusep \& Gio Carlo Giera, aen Seguier padre x figlio op het haere van 30 junij en den 6 july g'apostilleert en denzelve dag g'intimeert', Izmir, 10/07/1745, '[...] con l'idea maliziosa d'offuscare $\mathrm{p}$ tal mezzo la chiarezza delle vere, e candide nre. raggioni $[\ldots]$ '.

81 Ibid., '[...] nostro carattere [...]', referring to their reputation.

$82 \quad$ NACs, $\mathrm{N}^{\circ} 317$, 'Treplicq van Seguier padre $\mathrm{x}$ figlio opt replicq van Giusep.e x Gio Carlo Giera van den 10 deezer g'appostileert den 14 detto en ook g'intimeert', Izmir, 13/o7/1745, '[...] troquer une barre d'or, contre une barre de fer [...]'. 
secure a freight for Svanson's ship. The firm had been charged with the commission to procure merchandise for the return trip of the vessel from Izmir to Livorno. The faster the ship could leave, the better it was for Giera, and according to father and son Séguier, this was telling of Giera's true character - he had sacrificed Butini's interests to further his own, a very serious accusation in a world in which reciprocity was key to the good functioning of trade. ${ }^{83}$

Unsurprisingly, the Giera firm called the accusations lies, and they felt they had done nothing wrong. They insisted for Daniel Alexander de Hochepied to reach a verdict quickly so they would not have to suffer further insults. ${ }^{84}$ Exactly one month after the initial request, de Hochepied, without seeking any recourse to his Dutch assessors or other traders, ruled that the Giera firm was to deliver all the Angora yarn to the Séguier firm. Should the later refuse to take it back, Giera had to sell it with the best interest of the owner, Butini, in mind. ${ }^{85}$ The Séguier firm chose to appeal, but no traces of it were found. In the first instance, the reasoning of the plaintiff had been founded on the idea that the Giera firm had broken the rules of trade, and they had done so for their own profit and to the detriment of the person who had hired them to act as intermediary. This meant the reputation of the Giera firm was on the line, a crucial asset, particularly in the Levant, where European firms were mainly active as commission traders for merchants in Europe.

Luckily for them, the Swedish consul had employed the Giera firm as means of deception. The double order given by Butini to sell his merchandise in Izmir, on 27 April to Giera and on 30 April to Séguier, left enough space to doubt Butini's orders, a doubt that Séguier was not able to dispel. The Giera firm was aware they were used to disguise the true ownership of goods as insurance against corsairs. Butini's revelation about the actual consignment to Séguier had come too late, and Giera might have taken advantage of this to win a commission. Séguier tried to save the argument by stating that, even in the case that Giera had been the rightful commissioning agent, he had done a very bad job. This made the court assume its most common role - as a tribunal that had to judge the reputation and liability of an intermediary in trade. It is not clear whether Daniel Alexander de Hochepied was Swedish vice-consul at the

83 Ibid.

84 NACs, $\mathrm{N}^{\circ} 317$, 'Treplicq van de ss.i Giusep:p \& Gio Carlo Giera, op dat van de ss Seguier padre $\mathrm{x}$ figlio van den 13 July den 19 ditto g'appostilleert, en ook g'intimeert aen d.t s: Seguier x C', Izmir, $17 / 07 / 1745$.

85 NACS, $\mathrm{N}^{\circ} 317$, 'Sententie vant voldongen proces, van Seguier pere et fils en Giuseppe $\mathrm{x}$ Gio Carlo Giera gepronuncieert door haer Ho: mo: consul den 21 Julij 1745 en't appel van Seguier ex ondert zelve', Izmir, 21/07/1745. 
time - his son would assume that function later, after he had also taken over his father's duties as Dutch consul. If this was indeed the case, Daniel Alexander de Hochepied at no moment mentioned it as relevant to adjudicating a case that involved goods belonging to a Swedish vice-consul in another locality. ${ }^{86}$ It is possible that de Hochepied did not want to reward Butini's deceitful behaviour and therefore ruled in favour of Giera, although that need not be motivated necessarily by de Hochepied acting as Swedish vice-consul to keep a fellow Swedish vice-consul in check.

\subsection{The Possibility of Appeal}

For intra-European disputes, once the appropriate court was selected, the adjudicating process can hardly be distinguished from intra-Dutch proceedings. The fact that the plaintiff was not Dutch had no procedural consequences. The nature of documents submitted to the court stayed the same - requests, replies, counter-replies, witness statements and business documents. Most of the written evidence was filed in another language, but the court had ample experience with Italian, English and French. What was different was the manner in which the documents were registered. In intra-Dutch cases, both parties delivered their documents to the Dutch chancery. The chancellor was not only responsible for showing what was brought in by one litigant to the other, notifying the latter that a reply was due within a certain time, but also for registering all of the documents used in a trial in the chancery's registries. ${ }^{87}$ When needed, the chancellor was also charged with selecting extracts from some of the material relevant to a particular case and with verifying that copies were identical to the original documents. Language could create an additional requirement - procuring a good and truthful translation. ${ }^{88}$

The responsibilities of the chancellor in instances of intra-European litigation were shared with his colleague at the consulate of the other litigant. Both parties were allowed to submit all of their materials to the court at the

86 For the consular functions of Daniel Alexander and his son Daniel Jean de Hochepied, see Schutte, Repertorium der Nederlandse vertegenwoordigers, pp. 335-336.

$87 \quad$ For the Dutch consular court, they have been preserved in eighteen volumes for the period between 1741 and 1810 . All of case $\mathrm{N}^{\circ} 33 \mathrm{O}$, the dispute between Ouckama and Wijnands \& Kramer, for instance, can also be found in NACs, $\mathrm{N}_{2} 204$ ('Register der Nederlandsche kanzelary te Smyrna gehouden door den heer kanzelier Johann Fred.r Mann begonnen den 3 january 1764 . Geeindigd den 4 april $\left.1765^{\prime}\right)$, pp. 84-187.

88 This was more important when Greek, Hebrew, Armenian or Turkish was concerned. There were sufficient shared languages between Europeans (and Ottomans) in the Levant, mainly Italian. On the use of shared language in the Mediterranean, see Dursteler, 'Language and identity in the early modern Mediterranean'; and his 'Speaking in tongues'. 
chancery of their own consulate - if one existed. ${ }^{89}$ The evidence clearly indicates that it was common practice for merchants to file a request, or a reply to a request, in the chancery of their own consulate, which would then ensure that the chancery of the Dutch consulate would get a copy of the document, which was subsequently added to the case documents preserved at the Dutch chancery and registered in the chancery's books. This made the role of the chancellor in ensuring the veracity of the submitted documents even larger than in intra-Dutch litigation.

The biggest difference with intra-Dutch litigation lay in the possibility of appeal. When a case between Dutch litigants that had been tried by the consul was appealed, it had to be done at a tribunal that stood higher in legal hierarchy. In the United Provinces, these were the Hof van Holland (see figure 5) and the Hoge Raad, and in the Levant, appeals were made at the court of the Dutch ambassador in Istanbul. ${ }^{90}$ Matters were more complicated in litigation between Europeans, as these belonged to entirely different jurisdictions. In the United Provinces, such a matter was resolved by offering foreigners equal access to the higher courts. In the Levant, a parallel solution was not so easy. Some of the cases include a request of appeal, which was registered at the consular court, but to be adjudicated at another court. In intra-Dutch litigation, appeals were adjudicated by the Dutch ambassador, but in intra-European disputes, the choice was not so clear. The Ottomans offered Europeans access to their courts, which made it possible for Europeans to appeal there. They rarely seem to have done so, and the practice was actively discouraged by diplomatic representatives. ${ }^{91}$ The other logical solution was the use of forum rei for the appeal. In the new trial, the losing party became the plaintiff and the winning party the defendant. As the appeal had to be adjudicated before a higher court, the likelihood of such court being situated abroad was high in the context of intra-European commercial litigation.

Adjudicating an appeal in a locality that might be far away was not an attractive option, and the path to it was restricted by additional regulations. One was to exclude certain cases from appeal - in 1675, it was determined that the consular court could adjudicate in cases up to 100 lion dollars' worth, and that in those cases, no appeal was possible..$^{92}$ A second restriction obliged the losing

89 Otherwise, it would have to be done at the consulate of the nation under whose protection the merchant stood, or under whose jurisdiction someone's power of attorney stood.

9o See also pp. $265^{-272}$.

91 See pp. $272-277$.

92 Heeringa and Nanninga, Bronnen tot de geschiedenis, 2: pp. 187-204, 'Reglement voor den resident tot Constantinopelen, consul tot Smirna, ende Nederlantsche natie in de Levant 
party to pay a caution equivalent to the money he had been sentenced to pay. ${ }^{93}$ In practice, merchants requesting an appeal regularly had to be reminded that, in order for the appeal to happen, they had to pay first: 'Homero is master of the appeal, but he has to follow the laws of appeal, that is deposit the sum, or provide caution, and then he can appeal.'94 These restrictions were not at all uncommon in the context of commercial litigation; the merchant court of Paris forbade appeals on sentences involving sums lower than 500 livres, and even in cases of appeal, the sentence would have to be executed without hindrance before the appeal took place, a measure that seems to have lessened merchants' desires to appeal unfavourable sentences. ${ }^{95}$

Another restriction - in the Dutch Levantine context - can be found in the early regulations issued by Cornelis Haga in 1616. These did not allow nonDutch litigants to appeal a sentence issued by a Dutch court in the Levant, although, in practice, Haga's regulations were violated, and foreigners did appeal Dutch consular verdicts before the Dutch ambassador - the competent higher court. ${ }^{96}$

In 1787 , a Greek Ottoman who was a Ragusan protégé, and thus legally considered a Ragusan subject, chose to appeal a sentence issued by the Dutch consul in Salonika in a dispute he had as plaintiff with another Greek, who was a Dutch protégé and the defendant in the case. ${ }^{97}$ As the Dutch protégé had won the case, and was thus taken to court as a defendant again, forum rei dictated that the court of the Dutch ambassador was the competent tribunal. The Dutch ambassador at the time, Frederik Gijsbert van Dedem, went to administer justice 'en cas d'appel', assisted by the advice of 'four neutral and

residerende respective, sooals hetselve bij de heeren Directeuren van den Levantschen handel aen H.H.M. is overgegeven, en bij deselve weder aen den Consul van Dam gesonden', 1675 , on p. 197.

93 Cau, Groot placaet-boeck, 2: pp. 1335-1338, 'Acte, voor den consul van Aleppo, noopende de judicature, \&c.', 17/o2/1616.

94 NACs, $\mathrm{N}^{\circ} 343$ ('Papieren aangaande de process tusschen Alexander x Sottira x Gerrit van Brakel geboekt off geregistreerd op $\mathrm{f}^{\circ} 33^{2}$ tot $345,1769^{\prime}$ ), Note from the Dutch consul to the Dutch chancellor, Izmir, 30/05/1769, 'Homero is meester over 't appeleeren maar hij moet de wetten van 't appel volge dat is de somma depositeere, of borgtogt geeven, dan kan hij appeleeren.' This note, which was written to discuss progress in a number of cases with the chancellor, was preserved in the documents of another trial.

95 Kessler, A revolution in commerce, pp. $5^{1}$ and 102.

96 Such violations were not particularly uncommon either. The restriction of appeal to nonDutch litigants of 1616 was replaced in the 1675 proposal by an article that specifically stated this possibility of appeal. Although it was not turned into law, several of its articles must have reflected legal practice; see pp. 95-104.

Which explains the competence of the Dutch consular court in Salonika. 
irreproachable persons. ${ }^{98}$ The persons chosen were three consuls of other nations and an individual. Other evidence further confirms that the decision to follow forum rei in the case above was not a rarity. In 1766, the French firm of François Séquard \& $\mathrm{C}^{\circ}$ had filed a petition against the Tuscan chancellor Orazio Capirossi in a case related to protested bills of exchange, for which he held Capirossi responsible. As the Dutch consul was also vice-consul of the Grand Duchy of Tuscany (and Capirossi was, as chancellor, an employee of the Dutch consul in his position as the Tuscan representative), Capirossi was allowed to defend himself before the Dutch consular court following forum $r e i$. He was found not liable for the bills, and Séquard was condemned to pay back a sum Capirossi had already paid, while his claim for payment of the four bills was dismissed. As Tuscan vice-consul (and consular judge), Daniel Jean de Hochepied did not rely on his usual Dutch assessors in this case. This did not mean, however, that he was adjudicating by himself. For this case, he was assisted by a Genoese, a Ragusan, and an English merchant - confirming the importance of using the expertise of merchants in the adjudicating process. ${ }^{99}$

Séquard appealed, and he followed forum rei, turning to the 'lords delegate judges of Florence or any other superior tribunal that was competent.'100 Séquard even provided an address in Florence, with a fellow French trader, which was to serve as his domicile during the appeal procedure. ${ }^{101} \mathrm{He}$ must have been convinced that he could win the case. It might be that, in the absence of a Tuscan ambassador in Istanbul, the highest Tuscan court was the natural and legal choice for appeal, and the addition of 'tout autre tribunal superieur' suggests that Séquard simply was not sure under what jurisdiction this had to be tried. Research on the legal functions of the French consuls in the Mediterranean demonstrates that there was a degree of freedom in choosing

98 NA, $\mathrm{N}^{\circ} 1.02 .20$, 'Archief van de Legatie in Turkije, 1668-1810 (1811)' (hereafter NALT), $\mathrm{N}^{\circ} 1274$ ('Pièces relatives au procès entre Hagi Nicola Papasoglou barattaire de Raguse mon beau fils Anastasio di Giovanni barattaire de Holl.de à Salonique, 1787'), Declaration by Ambassador Gijsbert Baron van Dedem, Istanbul, April 1787, '[...] quatre personnes impartiales et irreprochables [...]'. For Ambassador van Dedem, see Schutte, Repertorium der Nederlandse vertegenwoordigers, p. 313 .

99 NACs, $\mathrm{N}^{\circ} 337$ ('Proces tusschen Capirossi \& Francois Siquard \& $\mathrm{C}^{\circ}$ van 21 feb 1766 tot 30 maert 1767'), 'Request van Fran.co Sequard aen den Franse consul weeg: pretentie op Cappirossi', Izmir, 21/o2/1766 (the request was made at the French consulate and sent to the Dutch/Tuscan consulate); and 'Sententie van den here Consul de Hochepied in de affairen tusschen Fran: Sequard \& $C^{\circ}$ \& Capirossi', Izmir, 19/o2/1767.

100 NACs, $\mathrm{N}^{\circ} 337$, 'Acte van appel van Fran: Sequard \& $\mathrm{C}^{\circ}$ teegens de sententie van dato 19 feb: anno courant', Izmir, 30/03/1767, '[...] les seigneurs juges deleguez a Florence, ou a tout autre tribunal superieur a qui la connoissance en apartiendra [...]'.

101 Ibid. 
an appeal court in intercultural litigation. French consular courts in Livorno and Tunis were used as appeal courts, both by French and non-French nationals. A treaty concluded in 1616 between Jacques de Vincheguerre, a knight of Malta working for the city of Marseille, and Yüsuf Dey, the dey of Tunis, contained a clause determining that the French consul in Tunis was allowed to adjudicate disputes between European Christians and those who recognised the French consul. ${ }^{102}$ This apparently codified existing practice, as Italians had been issuing appeals at the Tunis consulate against sentences issued in Pisa or Livorno. ${ }^{103}$ An alternative to this form of legal forum shopping was the establishment of the competence of specific courts for the appeal against sentences about commercial disputes amongst traders of various nations. When Ancona became a free port (portofranco) in 1732, hoping to attract foreign trading communities, regulations stipulated that traders who were dissatisfied with the sentences from their consuls were allowed to appeal at the Consolato di Mare of Ancona, 'without seeking refuge to any other tribunal.'104

\section{$2 \quad$ Unravelling the Web of Commission Trade in Court}

\subsection{Crossing Physical Distance by Power of Attorney}

The Giera case was relatively simple, with easily definable parties, a concrete action that was being disputed and clear jurisdiction. It took a total of three rounds of declarations and counter-declarations before the consul reached a verdict, and although excerpts from correspondence and accounts were included in the declarations, no additional evidence needed to be submitted. In many other cases, things were not so straightforward, as illustrated by a complicated case adjudicated in Izmir by Consul Daniel Jean de Hochepied in 1766. In August that year, Jacques Forêt, an arms dealer from Liège, gave a power of attorney to a Dutch merchant in Izmir, Gerrit van Brakel, to act on his behalf in a court case against the Dutch firm of Dirk Knipping \& $\mathrm{C}^{\circ}$, also merchants in Izmir. The document allowed van Brakel to use all legal means he

\footnotetext{
102 Guillaume Calafat, 'La jurisdiction des consuls français en Méditerranée: litiges marchands, arbitrages et circulation des procès (Livourne et Tunis au Xviı siècle)', in De l'utilité commerciale des consuls, eds. Arnaud Bartolomei et al.

103 Ibid., pp. $15^{-16 .}$

104 De Nederlandsche maandelyke post-ryder, medebrengende berigten van de voornaamste en gedenkwaardigste staat- en oorlogszaken, die in en buiten 't Christenryk zyn voorgevallen, beneffens de daar toe behoorende bewysstukken. Voor de maand may, 1732 (Amsterdam, 1732), p. 520, '[...] zonder toevlugt te neemen tot eenig ander geregtshof [...]'; see also Il consolato della città d'Ancona ovvero raccolta dei privilegj, e de' capitoli (Ancona, 1777).
} 
could to obtain satisfaction for his principal. ${ }^{105}$ Forêt demanded restitution of some weapons he had sent to Knipping, as well as monetary compensation for several sales of weapons Knipping had concluded on his behalf, at prices lower than the minimum Forêt had set for them and for which he never would have given permission. The declaration had been drafted before a Liège notary and contained an official confirmation from the aldermen of Liège confirming the veracity of the deed. ${ }^{106}$

Liège was a Prince-Bishopric, part of the Holy Roman Empire, and the place became an important centre for arms production in 1492 when official 'letters patent' were issued by the French, the Burgundian Netherlands and the Habsburg Empire, in which they all recognised Liège's neutral status. ${ }^{107}$ The Prince-Bishopric had regulations in place ensuring the quality of firearms production since 1672 and maintained important trade connections with the United Provinces, which had purchased a great number of weapons there during the Eighty Years' War, as had the Spanish. ${ }^{108}$ It is not surprising that arms dealers in the Prince-Bishopric used middlemen in port cities in Holland to send their goods to destinations even further abroad, such as the Ottoman Empire. Dutch port cities were particularly interesting, as the Ottoman Empire had been the first state to recognise the independent United Provinces, and it even sent some support in the form of weapons and clothing for soldiers. These contacts were later expanded upon, and the Dutch sent maritime weaponry and ships to North Africa and exported handguns to the Ottoman Empire. ${ }^{109}$

Sometimes transactions went wrong, which happened in the case of Jacques Forêt in Liège and Dirk Knipping in Izmir. Knipping was an interesting member of the Dutch community of Izmir. He had been a partner in the firm of David van Lennep, one of the most important Dutch merchants in Izmir, and William Enslie until his marriage to a Greek woman in 1758 ended his involvement.

105 NACS, $N^{\circ} 339$ ('Gerrit van Brakel, Nederlands koopman te Smyrna, optredende namens Jacques Forêt te Luik tegen Dirk Knipping, Nederlands koopman te Smyrna, 1767'), 'Constitution general passée par monsieur Jacques Foret marchand d'armes sur la personne de monsieur Gerrit van Brakel negociant a Smirne', Liège, 25/08/1766.

106 Ibid.

107 W.S.M. Knight, 'Neutrality and neutralisation in the sixteenth century - Liège', Journal of comparative legislation and international law, 2:1 (1920): pp. 98-104.

108 See Steven J. Gunn, David Grummitt, and Hans Cools, War, state, and society in England and the Netherlands 1477-1559 (Oxford, 2007). Liège's tradition as an arms fabrication and trade centre continues to this day.

109 Alexander H. de Groot, Nederland en Turkije. Zeshonderd jaar politieke, economische en culturele contacten (Leiden, 1986), p. 12. For the efforts of a Jewish diplomat serving in Morocco and brokering deals between the Moroccan ruler and the United Provinces, see the biography of Samuel Pallache by García-Arenal and Wiegers, Samuel Pallache. 
After that, it seems Knipping and his wife embarked for Amsterdam, where he originally came from, but by August 1759, he was back in Izmir, where he established a new firm in partnership with Pieter Ouckama. ${ }^{110}$ Jacques Forêt had been one of the first traders to answer their call for commissions, and he started to send them weapons, using the firm of Herman van Coopstad in Rotterdam as an intermediary. He was not the only arms dealer from Liège starting to conduct business with Knipping \& Ouckama. ${ }^{111}$ By 1762, the partnership between the two Dutchmen had been dissolved, shown by a power of attorney sent from Rotterdam to Pieter Ouckama in an effort to claim money from the disbanded partnership between Knipping \& Ouckama. ${ }^{112}$ Knipping was elected as assessor for the Dutch nation in February 1763, which not only rendered him an element of the adjudicating system but also provided him with experience in litigation. ${ }^{113}$ Six months later, he became the only Dutch trader who managed to escape the fire of August 1763. He had not found housing in the 'Street of the Franks' (see figure 4), which was greatly damaged by the fire, but was living 'in a small house in the Armenian neighbourhood'.114 In the years after, Knipping stayed an independent merchant. He had not remained assessor for very long, as he was referred to as the 'former assessor' in a Dutch meeting held in Izmir in February 1766. ${ }^{115}$ The meeting discussed the appointment of Knipping as the provisional overseer for the payment of consular taxes by members of the Dutch nation, a service for which he was paid 600 lion dollars per year. ${ }^{116}$ Knipping held that position for at least six years, as a special meeting of the Directorate of Levant Trade in Amsterdam renewed his contract for a period of three years in September $1769 .{ }^{117}$ When he was summoned in court as defendant, he was thus a figure of distinction in the Dutch trading community of Izmir.

110 See p. 69; see also Hakkı Kadı, Ottoman and Dutch merchants, p. 203.

111 See pp. $155^{-157 .}$

112 NACs, $\mathrm{N}^{\circ} 498$, 'Volmacht van Looy \& van Spaen te Rotterdam voor Pieter Ouckama om gelden te innen die Dirk Knipping nog onder zich heeft uit de boedel van Knipping \& Ouckama', Rotterdam, o2/04/1762.

113 Heeringa and Nanninga, Bronnen tot de geschiedenis, 3: pp. 479-480, 'Notulen weegens installeeren der assessooren', Izmir, 17/02/1763.

114 Ibid., pp. 483-484, Consul Daniel Jean de Hochepied to the States General, Izmir, 24/o8/ 1763, , [... ] in een klijn huysje in de Armeense buurd'. This was also reported by newspapers in the United Provinces; see the Middelburgsche courant, 22/10/1763; see also figure 4.

115 The meeting is quoted in Heeringa and Nanninga, Bronnen tot de geschiedenis, 4, p. 27, '[...] geweesen assessor $[\ldots]$ '.

116 Ibid.

117 Ibid., pp. 136-137, 'Extra-ordinaris vergadering van de directeuren met de buitenleden te Amsterdam', 27/o9/1769. 
Jacques Forêt had been doing business with Dirk Knipping since at least 1759, and often together with a firm in Rotterdam, Herman van Coopstad \& $\mathrm{C}^{\circ}$. It seems that it was van Coopstad who established the contact and through whose hands the weapons were sent from Liège to Izmir. There, the weapons were sold by Ottoman middlemen, rendering the whole chain of transactions quite intercultural. In November 1759 Knipping, still in partnership with Ouckama, wrote to van Coopstad about an order he had received in Izmir for 2,400 pairs of pistols mounted in copper and with a slightly bigger lock than the pistols they had received before. Knipping \& Ouckama were interested in a deal in which they would be involved for a quarter, while the remainder was to be split equally between van Coopstad and his 'friends from Liège.'118 They were certain that van Coopstad would place the order with the firm of Jacques Forêt, Comhaire \& $\mathrm{C}^{\circ} .{ }^{119}$ Later that day, Knipping \& Ouckama wrote to the Forêt firm about the proposal, assuring them that van Coopstad would address them, even though a number of other arms producers in the Prince-Bishopric had already offered to produce weapons for van Coopstad at prices lower than those of Forêt and his partners. ${ }^{120}$ Knipping \& Ouckama were optimistic about Forêt's abilities to deliver the order, and they hoped it would lead to a more regular arms trade as friends. It seems that this initial transaction indeed led to the development of more durable business ties, and even after the partnership between Knipping \& Ouckama had been dissolved, the former continued to do business with Jacques Forêt and Herman van Coopstad until their dispute in 1767 .

A year after Forêt gave van Brakel power of attorney, the latter filed an official claim at the Dutch consular court in Izmir. ${ }^{121}$ In it, he demanded, on Forêt's behalf, 10,396:8 guilders from Knipping \& $\mathrm{C}^{\circ}$. This was to cover half the value of the 400 pairs of pistols sold in 1765 (f665:7 guilders), the value of the sale of 831 pairs of pistols sold to Pietro Ferrieri \& $C^{\circ}\left(f_{5}, 6 \circ 6: 5\right)$ in 1764 and, finally, the value of four boxes containing $53^{2}$ pistols and two boxes containing 95 flintlocks (snaphanen) sold in 1765 ( $\mathrm{f}_{4,121: 16) .}{ }^{122}$ Efforts to settle this sum directly with Knipping, Forêt's agent in Izmir, had failed, and Dirk Knipping seems to

\footnotetext{
118 NACS, $\mathrm{N}^{\circ} 490$, Knipping \& Ouckama to Herman van Coopstad \& $\mathrm{C}^{\circ}$, Izmir, o1/11/1759, '[...] Luykse vrienden $[\ldots]$ '.

119 Ibid. The partnership between Forêt, Comhaire and others must have disbanded by the time Jacques Forêt gave his power of attorney to Gerrit van Brakel, as no mention was made of that firm.

120 NACs, $\mathrm{N}^{\circ} 49$ o, Knipping \& Ouckama to Forêt, Comhaire \& $\mathrm{C}^{\circ}$, Izmir, o1/11/1759.

121 NACS, $\mathrm{N}^{\circ} 339$, 'Request van Gerrit van Brakel weegens de pretentie van Foret aen Knipping', Izmir, 21/08/1767.

122 For the 'snaphaan', an early modern improvement of the arquebus, invented in France around 1635, see Barry M. Berkovitch, The Cape gunsmith: A history of the gunsmiths and
} 
have registered some of the information incorrectly. The $83^{1}$ pairs of pistols had apparently been sold to the partnership of Pietro Ferrieri \& Robert Farrar, not to Ferrieri \& $\mathrm{C}^{\circ}$, at an acceptable price for Forêt, so van Brakel wanted to see the obligations showing the outstanding debt of the buyers. ${ }^{123}$ The four boxes of pistols and two boxes of flintlocks had been sold for too low a price, so van Brakel argued that Knipping had to participate financially in the loss, particularly as he, as commissioned agent, had written a letter to Forêt in 1765 promising to await new orders from him.

Knipping's writing demonstrated he was fully aware that he was not allowed to sell below a specific price limit, but he had done so anyway. To make matters worse, the money from that sale had not even been remitted to Forêt. Van Brakel suggested that Knipping had perhaps kept it for his own advantage, a cardinal sin for a commissioning agent. A second aggravating circumstance was that Knipping knew he had been selling to merchants that lacked money, making him responsible for the failure of the buyers to pay. For this, van Brakel demanded that Knipping make up Forêt's loss on the six boxes. As 'magistrate of the Dutch nation' and 'competent judge for both parties', the consul was asked to demand payment or obligations from Knipping for these transactions. ${ }^{124} \mathrm{De}$ Hochepied and the assessors, who included two of Knipping's former business partners (David van Lennep and William Enslie), ordered Knipping to settle his accounts with Forêt within the next ten days and to provide an obligation concerning the unpaid order of Ferrieri \& Farrar. ${ }^{125}$

The litigation that ensued quickly focussed on two of the claims: the sale of the $83^{1}$ pairs of pistols to the firm of Ferrieri \& Farrar and the four boxes containing 532 pairs of pistols and 95 flintlocks. The first transaction concluded in December 1764, but in July 1765, Knipping sent Forêt a letter informing him that Ferrieri \& Farrar had not paid yet, citing general difficulties paying several of their creditors. ${ }^{126}$ The second transaction had been made to a number of unspecified buyers, and Forêt had not yet received any money for that sale either, a sale which had been concluded against Forêt's orders and under the

gun dealers at the Cape of Good Hope from 1795 to 1900, with particular reference to their weapons (Stellenbosch, 1976).

123 The commercial relationship between Pietro Ferrieri, a Venetian, and Robert Farrar, an Englishman, is not exactly clear from the documents. They were mentioned as the buyers of Forêt's 831 pairs of pistols, and both were considered to be responsible for their payment. NACs, $\mathrm{N}^{\circ} 339$, 'Request van Gerrit van Brakel', Izmir, 21/08/1767.

124 NACs, $N^{\circ} 339$, 'Request van Gerrit van Brakel', Izmir, 21/o8/1767, '[...] magistraat der Nederlandse natie $[\ldots]$ ' and '[...] beijder parthijen competente regtere [...]'.

125 Ibid.

126 NACs, $\mathrm{N}^{\circ} 49$ o, Dirk Knipping to Jacques Forêt, Izmir, 21/11/1765. 
minimum price he had set. An adjustment van Brakel made in September 1767 to the current account between Knipping and Forêt from February 1766 shows that the four boxes from the second transaction had been sent from Rotterdam to Izmir on 3 May $1765 .{ }^{127}$

By the time of that adjustment, van Brakel had already received the power of attorney from Forêt. There are no concrete indications that the two men knew each other or had established a business correspondence earlier. It seems that Forêt's first letter to van Brakel was sent on 1 September 1766, a week after he gave him the power of attorney. Forêt was staying in Rotterdam at the time, where he found lodging through van Brakel's recommendation. ${ }^{128}$ In a letter to van Brakel written in May 1767, which included an earlier copy of a letter from December 1766, Forêt consistently referred to 'that miserable' Knipping ('ce miserable') as 'a rogue' ('un fripon'), a man who was 'unworthy of living' ('indigne de vivre'), and demanded that van Brakel, once he had received all the documentation he needed, take care of Forêt's interest as 'if it was his own' ('de vous emploier comme pour vous meme'). ${ }^{129}$ If Knipping refused to pay, he was to brought to justice. He had affected Forêt's business in such a way that his health and that of his children had suffered and promised that, should van Brakel manage to get Knipping convicted, he would reciprocate such a 'great work of charity' ('le plus grand oeuvre de charite') by offering him his own services - a pretty good return favour according to Forêt, who claimed to be so well-known in Holland that he was the man to go to in case of need. ${ }^{130}$

Clearly, Forêt's letter had been written in a state of emotion but also in the spirit of the merchants' style. At first sight, it might look like a call for help from someone who would not know who else to turn to, with Knipping being his main contact in Izmir. But there was more at play. One of the central characteristics of business correspondence was reciprocity. ${ }^{131}$ Merchants were in business together because they believed it would be profitable for

127 NACs, $\mathrm{N}^{\circ} 49$ \%, Copy of a sales account, Izmir, 20/02/1766; and 'Reekening courant tusschen Knipping \& Forêt', 1767 .

128 Writing letters of recommendation on behalf of fellow merchants who were travelling so they could dispose of credit, lodging and even entertainment, was a common favour given by traders to one another, and as such, it was part of the merchants' style. See Vanneste, Global trade, pp. 82-84; and Sebouh Aslanian, 'The "quintessential locus of brokerage": Letters of recommendations, networks, and mobility in the life of Thomas Vanandets'i, an Armenian printer in Amsterdam, 1677-1707', Journal of world history, 31:4 (2020): pp. 655-692.

129 NACs, $N^{\circ} 490$, Jacques Forêt to Gerrit van Brakel, Liège, 14/05/1767.

130 Ibid.

131 See Vanneste, 'Commercial culture', pp. 106-111. 
all parties involved. Essentially, of course, it was a manner of pursuing selfinterest through a balanced consideration of everyone's interests, but there was a strong reliance within the business community on the idea that everyone's self-interest was best served through reciprocity. ${ }^{132}$ In the early modern world of international trade, reciprocity was a generally accepted mechanism by which traders judged their peers' behaviour and by which they calculated the risks attached to future transactions. Whether a trader complied with the custom of reciprocity when engaging in trade with a fellow merchant or not influenced his reputation and the trust put in him by other traders. These in turn played a role in the merchant's efforts to build up an international network of business correspondents with whom the trader could engage in mutually advantageous and long-term commercial relationships. This is the reason why there are so many references in business letters to rendering service to one another and the importance of this as the basis for setting up mutually successful commercial enterprises.

All of this is evident in the rhetoric used by Knipping \& Ouckama when offering their services to Dutch correspondents as a new trade firm in Izmir in such emotional terms, referring to their own desire to 'serve their friends with loyal and honest actions' while also reiterating their conviction about the 'generosity' of these same friends. ${ }^{133}$ Forêt's offer of reciprocity to van Brakel was conditional, as it depended on van Brakel's performance before the Dutch consular court in Izmir, but it was a very real offer and most likely a valued one, as merchants were always on the lookout to expand their web of business contacts with new, trustworthy individuals. Reciprocity, perhaps, was the commercial equivalent of legal equity. Van Brakel was to be assessed by Forêt, which influenced his reputation, potentially in the eyes of every correspondent of Forêt, who, in case of a successful outcome, could vouch for van Brakel as a trader in Izmir who was able to defend the interests of a stranger.

It would have been unwise of Forêt to put all of his faith in van Brakel without trying to find an alternative source that could keep him up to date with the legal proceedings in Izmir. Forêt was also being informed of the state of his affairs in Izmir by the firm of Manolaki di Panaiotis and Jacob de Vogel. ${ }^{134}$ They informed Forêt about the identity of at least one of the mysterious buyers of

132 Harold J. Berman, Law and revolution: The formation of the western legal tradition (Cambridge, MA, 1983), pp. 344-345; see also pp. 173-181.

133 NACS, $\mathrm{N}^{\circ} 490$, Knipping \& Ouckama to Herman van Coopstad, Izmir, 29/og/1759, '[...] die onze respective vrinden met alle trouwe $\mathrm{x}$ eerlyke behandelingen tragten te bedienen $[\ldots]$ ' and '[...] genereusiteit $[\ldots]$ '.

134 See also pp. 248, 250, and 283-284. 
the pistols and flintlocks that had come in the four boxes. This man, still nameless in the correspondence, seems to have been 'Turkish'. Di Panaiotis and de Vogel must have already established a longer relationship with Forêt, because they were the intermediaries who delivered all of the relevant accounts about the affair to van Brakel. ${ }^{135}$ It is impossible, without the survival of all the relevant written evidence, to guess why Forêt did not choose Panaiotis \& de Vogel to represent his interests at the court. Perhaps he asked, but they declined. Perhaps he wanted a more neutral party, or at least a third party he would be able to observe through his other contacts. In any case, van Brakel had been recommended to Forêt by correspondents the arms dealer had in Rotterdam, Gerrit van Brakel's city of origin.

The power of attorney that van Brakel accepted on behalf of Forêt could enhance his commercial reputation and expand his business networks, but it also meant a substantial amount of work. The positives seem to have outweighed the negatives, because I have only found one example in which a merchant from the Dutch trading community of Izmir refused to accept a power of attorney to represent a colleague in a legal dispute. In 1770, the traders Salomon Lamera and F.H. Heffert were asked to act on behalf of Isaac Beaune, a merchant in Izmir. The latter had left town temporarily but was sued in court by Daniel Fremeaux on behalf of an Amsterdam firm that demanded payments from Beaune that were overdue. When the Dutch chancellor, accompanied by several witnesses, went to the house where Beaune's firm had been established to summon the defendant, they found one fellow trader, F.H. Heffert, willing to act as power of attorney while the other, Lamera, refused. Lamera explained he did not want to have anything to do with Beaune's firm and insisted the chancellor note it in the margin of the letter he had brought with him. Lamera's refusal did not have any legal consequences, but it is unclear whether his reputation took a blow and his business suffered from his refusal. ${ }^{136}$

Lamera might not have felt in any way attached to the Dutch community of Izmir, and in that sense, it might have been easier for him to refuse the power of attorney. He had other options, but for Heffert, relying on commissions from the United Provinces, damage to his reputation could quickly spread from the Dutch trading community of Izmir to clients in the Dutch Republic, and his business might suffer accordingly. His fellow traders in Izmir might also stop

135 NACs, $\mathrm{N}^{\circ}$ 490, Jacques Forêt to Gerrit van Brakel, Liège, 14/05/1767.

136 NACs, ${ }^{\circ} 349$ ('Papieren der proces tusschen Fremeaux \& Heffert, 19/o2/1770-19/o3/1771'), 'Acte van vertoonde procuratie aen de proc van Pieter Isaac Beaune \& $\mathrm{C}^{\circ}$ weegens de intresten van de heeren du long, De Conink \& Elliot te Amst met protest weegens gewygerde verantwoord', Izmir, 19/o2/1770. 
doing him favours. In any case, van Brakel's immediate acceptance to legally represent a stranger from a foreign land in court was not at all exceptional, and the potential commercial advantages this legal effort could bring were substantial. Van Brakel was a relatively new member of the Dutch trading community of Izmir at the time, and he had a lot to win by obtaining the gratitude of Jacques Forêt, who would be able to ensure future commissions for him.

\subsection{The Trial}

After van Brakel filed his petition with the consular court in August 1767, a relatively short legal procedure ensued. Knipping disputed the claim of 10,396:8 guilders and sent a number of current accounts between him and Forêt along with his written reply to support his argument. ${ }^{137}$ The main task of the consul and his assessors was to determine who was responsible for the two disputed transactions. The task was complicated by the fact that Knipping was in financial difficulties, with several of his creditors pressing him to pay his debts. It made all goods he was to receive on commission vulnerable. Knipping's financial difficulties were well-known, because Consul de Hochepied had issued a declaration in November 1766 in which he confirmed that Dirk Knipping was still fully in charge of his company (Dirk Knipping \& $\mathrm{C}^{\circ}$ ) and that the management of his affairs had not been taken away from him, in spite of the financial troubles he was having. ${ }^{138}$

Van Brakel and Knipping were fellow merchants. Van Brakel not only knew Knipping personally, he also had been somewhat involved in Knipping's business activities on Forêt's behalf. Knipping stated that by the time the shipment of four barrels of pistols and two cases of flintlocks arrived, van Brakel was well aware of the financial difficulties Knipping was in. Gerrit van Brakel offered his help and suggested that the merchandise should be endorsed to him instead, and he would pay the import taxes on it. ${ }^{139}$ Knipping accepted van Brakel's proposal, which might have been an attempt to take over as a commissioner for Forêt, hoping to gain more business prospects that way. While Knipping did not use this information to place van Brakel in a bad light, this part of the story is reminiscent of the discussion between Ouckama and Clement, van Sanen, van der Zee \& $\mathrm{C}^{\circ}$. The latter stood in the same legal position as van

137 NACS, ${ }^{\circ} 339$, 'Request van Gerrit van Brakel', Izmir, 21/08/1767; and 'Antwoord van Knipping aen Braekel wegg: Forret te luijk', Izmir, 28/o8/1767.

138 NACs, $\mathrm{N}^{\circ} 162$ ('Minuten kanselarij, 1766 '), 'Declaratie van den heere consul aen Dirk Knipping dat hem het bewind sijner saeken door niemand alhier is affgenoomen, maar alles ten volle is in handen gelaeten', Izmir, 19/11/1766.

139 NACS, $\mathrm{N}^{\circ} 339$, 'Antwoord van Knipping aen Braekel wegg: Forret te luijk', Izmir, 28/o8/1767. 
Brakel, holding power of attorney for a geographically remote plaintiff, and also offered a commercial service to a fellow trader in the same community. That case sparked a debate on the nature of reciprocity. Here, Knipping used the discussion to shift part of the responsibility.

Whatever van Brakel's motives behind the proposal were, Knipping agreed, as it guaranteed the safety of Forêt's goods from Knipping's creditors in case he would go bankrupt. But when one of these creditors, a Turk named Hagi 'Abdullah, came to Knipping to claim his money, van Brakel put the weapons in the hands of Knipping's Jewish broker, Elia Hemzy, making them again vulnerable to any creditor's claim. Knipping insisted the weapons be put securely in the chancery, again to prevent any damage to Forêt's interests, but 'Abdullah became angry and threatened to take Knipping to an Ottoman court if he failed to pay his debts. ${ }^{140}$ Knipping felt he had no choice but to hand over part of the weapons to 'Abdullah, defending his decision by remarking that they were living in 'a Turkish land and were exposed to all avanias'. ${ }^{141}$ Avania was a term used by Europeans to label actions by the Ottoman authorities that they considered unjust; the meaning Europeans gave it was 'extortion.'142

Maurits van den Boogert, however, has shown that this negative interpretation was far from correct, inspired by a Eurocentric interpretation and incomplete understanding of Ottoman bureaucracy. It was derived from the idea that the capitulations, and the legal autonomy granted therein, were sacred, and every Ottoman action that could be interpreted as an infringement of the absolute nature of the capitulations was considered to be extortion. But this ignored the fact that the capitulations fit within the broader context of the Ottoman legal system and were balanced with a whole body of Ottoman kanun and Islamic law. ${ }^{143}$ Mostly, it was used to refer to payments to Ottoman bureaucracy that Europeans mistakenly thought of as unfair 'extortion in the Turkish style', or with certain legal actions that Europeans feared, did not understand or did not consider honest. ${ }^{144}$ The concept is thus often used in phrasing that

\footnotetext{
140 Ibid.

141 Ibid., ‘[... dewyl wy alhier in een Turks lant zyn x voor alle avanies bloot staan [...]'; see also pp. 308-312 for more on avanias.

142 For a detailed analysis of the concept of avania as used by Europeans, see van den Boogert, The capitulations, pp. 117-157; see also Merlijn Olnon, 'Towards classifying avanias: A study of two cases involving the English and Dutch nations in seventeenth-century Izmir', in Friends and rivals, eds. Hamilton et al., pp. 159-186.

143 Van den Boogert, The capitulations, pp. 117-157.

144 Heeringa and Nanninga, Bronnen tot de geschiedenis, 2: p. 10, '[...] geldafpersing in Turkschen stijl [...]'. The language is Heeringa's and is a clear use of a prejudiced stereotype.
} 
reflects the European perceptions of volatility and arbitrariness, such as 'out of fear of avania' or 'unheard of and tyrannical avania'. 145

Europeans felt victimised by these avanias and never hesitated to express as much to their fellow Europeans. Knipping's observation that he had no choice because otherwise he might have suffered some unjust Ottoman extortion is but one of many examples. He continued his letter by stating that he sold the remainder of the weapons rapidly, indeed at too low a price, but he only had done to pay off his most pressing debts and out of necessity to live. ${ }^{146}$

Regarding the weapons that had been sold to Ferrieri \& Farrar, Dirk Knipping insisted he continued to ask for their payment from the buyers. When that failed, he sought recourse to de Hochepied, who spoke with the English consul Anthony Hayes in an attempt to force Robert Farrar, an Englishman, to pay for the weapons. The conversation had some success, as Ferrieri issued two obligatory notes to cover the sale. The first was dated 24 December 1764 and was worth 2,039:50 lion dollars, while the other, dated 18 February 1765 , initially had been worth 2,700 lion dollars but 1,00o had been paid already. The second of them had already been in van Brakel's possession since October 1765 , long before the trial. With this in mind, Knipping was startled by the financial claim made by van Brakel in Forêt's name on that transaction. ${ }^{147}$ Knipping's main argument was that he had always attempted to protect Forêt's interests, as a good agent, in spite of the financial difficulties he was going through. Knipping felt the accusation that he should have known better than to sell to a buyer with financial difficulties - Ferrieri \& Farrar - was unjust and irresponsible, particularly as van Brakel himself had conducted business with Farrar ten months after the sale of the weapons, which was proof that van Brakel also had kept trust in the Englishman's creditworthiness. Knipping further stated that he was committed to repay all of his own creditors in full at a rate of ten percent per year over a period of ten years. He could, on the other hand, not provide any financial security for this promise, only his honesty, as he was living

145 Ibid., pp. 447-449, Theyls aan de directeuren, Cairo, 24/o1/1664, on p. 447, '[...] uijt vreese van avenie [...]' and Heeringa and Nanninga, Bronnen tot de geschiedenis, 3: pp. 379-39o, 'De Nederlandsche kooplieden te Angora aan consul tresorier, assessoren en leden van de Nederlandscha natie te Smirna', Izmir, o1/12/1757, on p. 349, '[...] de ongehoorde en tirannise avania $[\ldots]$ '.

146 NACs, $\mathrm{N}^{\circ} 339$, 'Antwoord van Knipping aen Braekel wegg: Forret te luijk', Izmir, 28/o8/1767.

147 Ibid. More information on the obligations can be found in the final verdict. NACs, $\mathrm{N}^{\circ} 339$, 'Sententie \& a weeg: de differentie van Knipping $\mathrm{x}$ van Brakel weegens Forret te Luijk', Izmir, o6/10/1767. Hayes was consul in Izmir between 1762 and 1794. Wood, Levant Company, p. 255 . 
parsimoniously with his wife and children, relying on the little income he was making as overseer of the Dutch consular taxes. ${ }^{148}$

Knipping's argument was crucial in the court's assessment of his responsibility. It seems that he had committed a cardinal sin for an agent by selling goods on behalf of his principal but under the minimum price that had been set. ${ }^{149}$ If he was found guilty, Knipping's reputation would suffer. As his financial difficulties were already publicly known, he risked losing all of his reputational assets. It might incline other merchants to stop doing business with him, and Knipping might never fully recover. It was therefore very important that Knipping was able to fully explain his actions. The principal trader's lack of information on the market circumstances abroad was a common problem that agents faced. Traders complained regularly in their letters to correspondents that the prices fetched for their goods were too low. It made all the difference whether the agent could convince his principal, and the trading community at large, that such low prices had nothing to do with his commercial abilities but everything to do with the state of the market. ${ }^{150}$ Agents sent long letters to their principals, explaining the circumstances behind transactions, and Knipping had done the same for Forêt. ${ }^{151}$ In this particular case, Jacques Forêt had provided van Brakel with one such letter, so it could be demonstrated to the court that Knipping had gone against Forêt's orders. In the letter, Knipping argued that market circumstances were so bad he would wait on new orders from Forêt, because no transaction could be concluded at the price minimum that had been set. ${ }^{152}$ Gerrit van Brakel argued that, contrary to what Knipping wrote in the letter, he continued to sell, but under the price minimum set by Forêt. This, of course, was motivated by Knipping's financial troubles. He continued to sell so he could use some of the money to pay off his debtors - something Knipping had already admitted - but also to secure the commission, which was in his own interest but not necessarily in that of his principal. ${ }^{153}$

The fundamental issue was about creditworthiness, not only Knipping's but also that of the buyers he had chosen. For the plaintiff, it all clearly

\footnotetext{
148 NACs, $\mathrm{N}^{\circ} 339$, 'Antwoord van Knipping aen Braekel wegg: Forret te luijk', Izmir, 28/o8/1767.

149 See also pp. 159-160.

150 Such claims could be hard to verify and traders tried other channels to obtain confirmation of such information. See also pp. 170 and 177.

151 See, for instance, $\mathrm{NACS}, \mathrm{N}^{\circ} 490$, Knipping \& Ouckama to Herman van Coopstad, Izmir, o1/ $11 / 1759$.

152 NACS, $N^{\circ} 339$, 'Request Gerrit van Brakel', Izmir, 21/o8/1767 ; and 'Lettre de Vienne a Monsieur Jacques Foret Liege p adresse de messrs Bongaene \& Panchaud a Constantinople le 21/11/1765 Vienne le 26/11 recu de vos tres hbles serv. p freres Smitmer', Izmir, 18/o9/1765. 153 Ibid.
} 
demonstrated that Knipping had acted as an incapable agent at best and as a fraudulent one at worst. One of the central questions that needed to be answered was to what extent Knipping had known about Ferrieri \& Farrar's creditworthiness. The answer determined Knipping's liability in the financial fiasco of that transaction. It seems that Knipping's argumentation was convincing, because van Brakel accepted it. He expressed his willingness to procure payment for the two obligations in his hands. The other transaction, involving Hagi 'Abdullah, was not so easily resolved - and maybe this can be explained by the fact that Knipping had referred to van Brakel's involvement in it, which meant his reputation was now also at stake. Van Brakel replied to Knipping's narrative by writing that Knipping had been dishonest, because he had only given the weapons to the broker at Knipping's behest, not because he had been pressured by Hagi 'Abdullah. He further stated that Knipping's justification of selling below the set price so he could pay off his debts and live was completely unheard of: 'where in the world has it been heard of that someone might take the goods of another, and to dispose of them to his own liking, to pay preferential and other debts, and to survive, and to make a price to his own desire [...] I say nowhere in the world'. ${ }^{154}$ Van Brakel found Knipping's proposal of reimbursement in ten years 'completely unreasonable', but he accepted it nevertheless so he could show the whole world that he was willing to settle affairs 'without having any desire to ruin the debtor and his family'.155

Van Brakel not only tried to salvage his own reputation, but his words also echo commercial morals from within the international trading community. Creditworthiness was a crucial asset for traders, because no international trade existed without credit. ${ }^{156}$ They could always be broken because somebody got into trouble. Bankruptcy was not uncommon in the early modern period, and what happened to Knipping could easily have happened to van Brakel as well particularly considering the fact that van Brakel had been doing business with

154 NACs, $N^{\circ} 339$, 'Replicq van Gerrit van Brakel weegens Knipping de affaires van Forret', Izmir, 12/og/1767, [...] waar is ooit in de weereld gehoort, dat imand het goed van een ander mag neemen, daar over na eigen wel behaage te disponeeren geprefeerde en andere schulden te betalen, en daar van t eleven \&ca en dan dezelve nog in de prijze zoo maar na eijgen believe te stellen, ofte reguleeren [...] ik zegge nergens in de weereld'.

155 Ibid., '[...] geheel onreedelijk [...]' and '[...] zonder den debiteur off zijne familie te willen ruineeren $[\ldots]$ '.

156 John Smail, 'Credit, risk, and honor in eighteenth-century commerce', Journal of British studies, 44:3 (2005): pp. 439-456. For a case study linking credit and reputation, see Zahedieh, 'Credit, risk, and reputation'; see also Julian Hoppit, 'The use and abuse of credit in eighteenth-century England', in Business life and public policy: Essays in honour of D.C. Coleman, eds. D.C. Coleman and N. McKendrick (Cambridge, 1986), pp. 64-78. 
the same insolvent clients. Fairness in judgment was important. In that sense, van Brakel's willingness to resolve the case without harming Knipping any further fits with the behavioural norm that dictated that one should look out for one's peers. While the self-sacrificing nature of van Brakel's easy acceptance of a solution might have been rhetoric; it was also a way of demonstrating to his peers that he had not set out to destroy a colleague's firm that was already in trouble. In other words, van Brakel was showing himself, and by association also the man he represented in court, Jacques Forêt, to be a man one could enter into business with. This might have been the most important aim van Brakel set out to achieve when he accepted Forêt's power of attorney. Forêt used very strong language against Knipping, Ferrieri and Farrar, calling all of them rogues. ${ }^{157}$ Knipping was bankrupt. Amidst all of this, van Brakel could emerge as the voice of reason, a merchant one could count on for future commissions but also for upholding the merchants' style in all fairness and reciprocity.

In the same atmosphere of reason, the consul and assessors read all the written statements and asked both parties to appear before them in person for interrogation. The verdict that followed stipulated that Knipping endorse both of Ferrieri's obligations to van Brakel. This made Ferrieri and Farrar direct debtors to van Brakel, acting on behalf of Forêt, saving the latter from further involvement in Knipping's bankruptcy. The sentence continued that Knipping had to pay 4121:16 guilders, the amount claimed by van Brakel, for the $53^{2}$ pairs of pistols and 95 flintlocks. At the same time, the court agreed on the ten-year plan Knipping proposed for repayment and on the plaintiff's claim for a caution, so they sentenced that half of Knipping's yearly reimbursements would have to come from his salary as overseer of the taxes. He had to promise 'as an honourable man' to pay the other half when due. ${ }^{158}$ Should Knipping fail to pay, van Brakel could sequester his person and goods. Knipping was also sentenced to pay the expenses of the trial. Both parties agreed to this settlement of affairs. 159

The sentence made Knipping partially responsible but still allowed him to try to save his business. He proceeded to do so, and when he attempted to reclaim money from a business partner in Rotterdam, Herman van Coopstad, in January 1769, Knipping asked legal help from the man who had been successful in defending Forêt's interests a little over a year earlier - Gerrit van Brakel. There clearly was no animosity between the two former adversaries.

\footnotetext{
157 NACS, $\mathrm{N}^{\circ}$ 49o, Jacques Forêt to Gerrit van Brakel, Liège, 14/05/1767.

158 NACS, $\mathrm{N}^{\circ} 349$, 'Sententie \& $\mathrm{a}$ weeg: de differentie van Knipping $\mathrm{x}$ van Brakel weegens Forret te Luijk', Izmir, o6/10/1767, ‘[...] als een eerelijk man [...]'.

159 Ibid.
} 
The transaction that Knipping disputed had to do with a sale of 912 pairs of pistols, which was concluded in January 1765 with Pietro Ferrieri. Van Coopstad had been involved for a quarter of the deal, and in 1769, he still owed Knipping money related to this transaction. ${ }^{60}$ Knipping wanted to receive a bill of exchange, payable to Gerrit van Brakel, from van Coopstad, to settle affairs between them. Should van Coopstad refuse to furnish it, he authorised Gerrit van Brakel to act as a plaintiff on Knipping's behalf in court against van Coopstad. ${ }^{161}$ This power of attorney must have meant that van Brakel had gone back to Rotterdam, a return that was most likely related to problems that arose between him and the consul. After Knipping, it was now van Brakel's turn to be plagued by financial problems: he failed to repay two Greek creditors and also was unable to meet his Dutch and Ottoman tax duties. ${ }^{162}$

Van Brakel's financial difficulties show that it had been a good decision to not press the case against Knipping too hard. The appeal Knipping made to van Brakel for his services also demonstrates that merchants did not bear resentment when they felt a case was handled fair and equitably. Beyond such considerations of mercantile custom, however, Van Brakel and Knipping might also have shared an understanding of the social problems one could get into in a foreign land. In 1767, Gerrit van Brakel married a Greek woman, something Knipping had also done almost a decade before. At the time, the marriage stirred controversy, because the Greek bishop in Izmir was fiercely opposing such marriages out of fear it might lead to the conversion of Greek women to the Roman Catholic or Protestant churches. The Dutch consul blamed van Brakel for some of the controversy. ${ }^{163}$

16o A declaration of debt had been left at the Dutch chancery, drafted in the presence of two witnesses, in which Ferrieri promised to pay Knipping for these pistols within six months. NACs, $\mathrm{N}^{\circ} 162$, 'Attestatie van P: Ferrieri dat aen Knipping \& $\mathrm{C}^{\circ}$ voor gekogte pistoolen Lx 4332 schuldig is', Izmir, 18/11/1766.

161 NACS, $\mathrm{N}^{\circ} 345$ ('Copye der documenten van D. Knipping teegens H. v. Coopstad in faveur van G. v. Brakel in Smirna'), 'Brieff aan Coopstad', Izmir, o7/o1/1769.

162 Heeringa and Nanninga, Bronnen tot de geschiedenis, 4: pp. 191-192, 'Extra-ordinaris vergadering met de buitenleden te Amsterdam', Amsterdam, 26/10/1774. Van Brakel's financial difficulties led to temporary expulsions from the Dutch trading community of Izmir, but he managed to return to exercise different functions. He became tax overseer in 1774 (see p. 248), chancellor of the consulate between 1783 and 1804 and treasurer from 1805 until his death in 1817. Schutte, Repertorium der Nederlandse vertegenwoordigers, p. 342. For his financial difficulties and his various petitions to return to the community, see NACs, $\mathrm{N}^{\circ} 229$ ('Stukken betreffende de schulden van de kanselier Gerrit van Brakel en diens tijdelijke schorsingen, 1770 \& 1804').

163 See NACs, $\mathrm{N}^{\circ} 223$, which contains documents on the quarrels arising out of the marriages between European Christians and Greek Orthodox women; see also pp. 70 and 299. 
Van Coopstad's refusal to fully pay Knipping for the transaction was related to the fact that he had sold to Ferrieri, a buyer known to have poor creditworthiness. It was the same argument that Forêt had made, but van Brakel had accepted Knipping's argument that Ferrieri was not known to stand in poor credit at the time Knipping accepted the sale. The same issue was at stake here, and the case file contains two declarations drafted by several merchants that Ferrieri was still trusted and stood in good credit at the time Knipping was doing business with him. These documents could free Knipping of all responsibility for choosing Ferrieri as a buyer. The most interesting feature of these declarations was their international nature. They were signed by over twenty merchants in Izmir, and their backgrounds were diverse. There are signatures in Arabic, Latin and Hebrew script, and Turkish names such as 'Ali Effendi, Sale Aga and Mehmed Aga, Jewish names such as Chaim Albaglie and Joseph Leon \& $\mathrm{C}^{\circ}$, and Greek firms such as Vitale, Zingrilara \& $\mathrm{C}^{\circ}$, Jani Mavrogordatos and Michele Curmusi next to the French firm of Tricon Frères \& $\mathrm{C}^{\circ}$ and the name of Gerrit van Brakel (see figure 8). ${ }^{164}$ This was a type of witness declaration that was frequently used in a court case as evidence. Often, these declarations indicated the opinion of part of the international merchant community on the behaviour of a fellow trader, and it was used to assess the individual responsibility of that trader in light of the merchants' style. Considering the international nature of the merchants' style, it was perfectly normal for such a declaration, even when issued in a specifically Dutch dispute, to contain the names of merchants with very different backgrounds.

The declarations were in support of Knipping, claiming he could not have known about Ferrieri's problems at the time of the sale. Additionally, these merchants confirmed they had also been doing business with Ferrieri at that time. This was perhaps the best weapon to use when defending someone's behaviour. It was hard to guess what an agent could and should know about a client he was doing business with. If twenty merchants wrote that they also continued to do business with the same client, it was very strong evidence that the agent could not have known and could thus not be held responsible. He should not pay for financial damages resulting from the transaction, and he should also not be branded as incompetent. These declarations were written to save Knipping's reputation, and the consul and assessors found them to be authentic. The remaining documents kept from this case do not include a final verdict, so the outcome remains unclear. It should be kept in mind that this

164 NACS, $\mathrm{N}^{\circ} 345$, 'Acte hoe hy buyten myn door andre is vertrouwt geweest', Izmir, o8/12/1768; and 'Copije attestatie van diversen dat Feriere in gen: 1765 nog in buonis was', Izmir, 29/ $12 / 1768$. 
EUROPEANS AT THE DUTCH CONSULAR COURT

239

Lminne@8xture 1168

Soi Inprascritti Neqoxiante, a fensali sigsta piarra

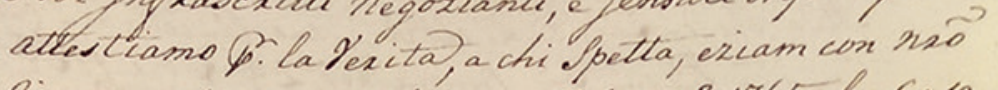
quuramento, come dal mede si Genno Mrbi. La Casa

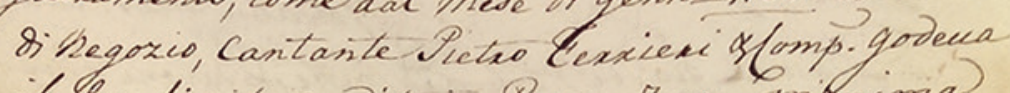
it Mo fiorito crodito in Pianza, hema minima ifuotta, e "Sope a nxă piena fognizione), ela Pexita c' iffiemiams si proprico pugno mpedeps.
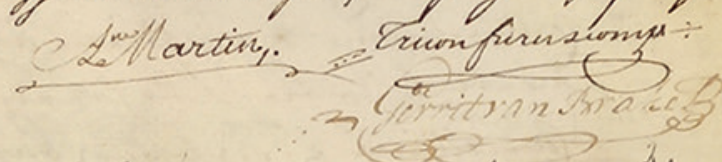

alligendif ale aga-

- Thangerlie liedé Mehmet Aga.

¿. Ghaim. Atbaglie

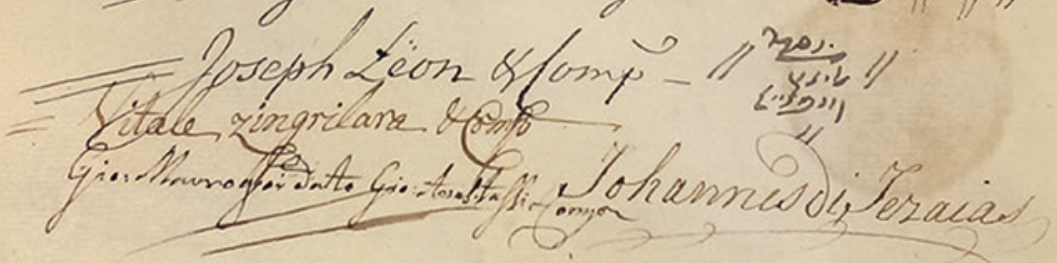

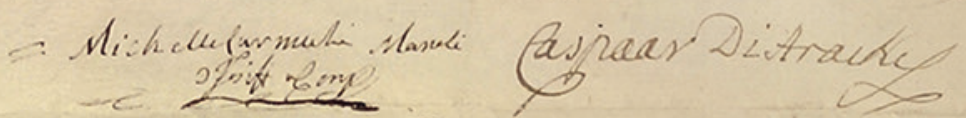

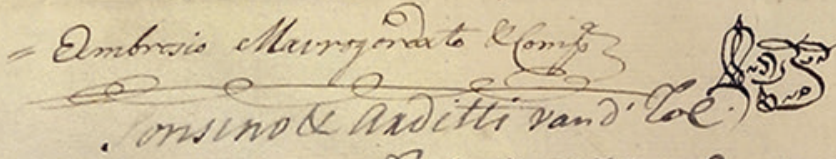

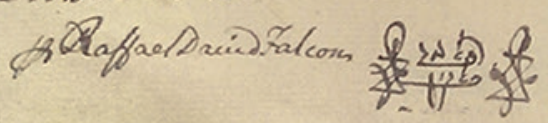

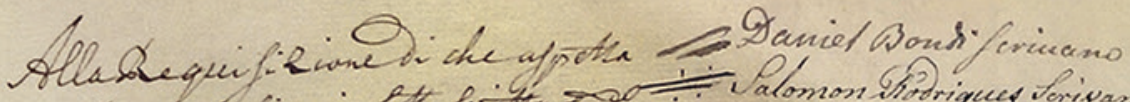

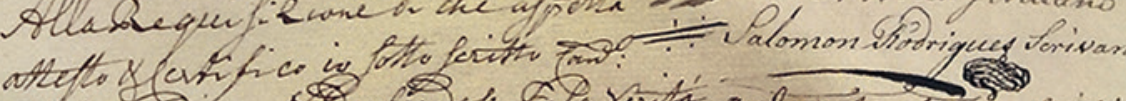

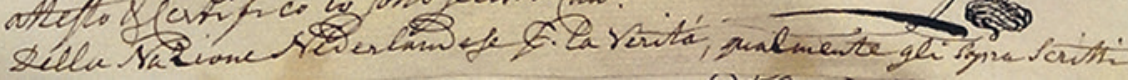

FIGURE 8 Signatures on a declaration of trust towards Pietro Ferrieri, 8 December 1768 FROM THE DUtCh NATiONAL ARChives, The hague (ARChives of THE DUTCH CONSULATE IN SMYRNA). PHOTO BY THE AUTHOR.

Tijl Vanneste - 9789004498235

Downloaded from Brill.come4/26/2023 01:15:45PM

via free access 
was not a case in which the consul was adjudicating. These were documents concerning a case in which van Coopstad was the defendant. Thus, the case would have needed to be tried in Rotterdam, and the fact that a number of documents have been preserved in the archives of the Dutch consulate in Izmir might be related to the fact that Knipping had given them to the chancellor so they could be checked for veracity and sent to Rotterdam.

\subsection{A Complicated Web of Entanglement}

The outcome of the 1767 case between Knipping and Forêt was relatively straightforward. The verdict was not harsh on Knipping, and he was not blamed for selling quickly to cover his own financial problems. Perhaps these problems softened the judgment of the consular court, as he was not sentenced to pay for all of the trial's expenses. He was warned, however, that he would be forced to pay all future legal expenses that would occur as a consequence of a failure to repay Forêt. In 1774, however, it became clear that Forêt had not forgotten all of his claims against his former agent. Although Knipping had been paying off Jacques Forêt at set times, he was still indebted to the arms dealer. In addition, it became clear that Forêt was still disputing part of the payment of the $83^{1}$ pairs of pistols that Knipping had sold to Ferrieri \& Farrar, in particular the 1,00o lion dollars that had been part of the obligation of 2,700 lion dollars and had been registered as paid by the time the remaining 1,700 lion dollars had been endorsed to van Brakel to collect on Forêt's behalf. ${ }^{165}$ The money never made it to Forêt, who felt Knipping, as the agent concluding the original sale, was still to blame.

Knipping was still in financial troubles but had been supported by the Dutch trading community in Izmir. At the time, all parties accepted the judgment in the first instance, and van Brakel had not appealed the consular sentence, which freed Knipping of all responsibility in the transaction of the 831 pairs of pistols. Jacques Forêt was apparently not happy with the outcome and perhaps also not happy with the position of van Brakel, who had acted on behalf of Knipping in the meantime, and this time, he decided to bring the case before a different court. He issued a power of attorney for legal representation to the Greek merchant Manolaki di Panaiotis, a barattaire of France and one of the merchants he had been in contact with to verify what was happening in Izmir at the time of the first trial against Dirk Knipping. ${ }^{166}$ On 10 December 1773, di Panaiotis petitioned the judge under whose jurisdiction he fell, the

165 See p. 233 .

166 For more on Manolaki di Panaiotis, see pp. $282-285$. 
French consul in Izmir, Charles de Peyssonnel, to sequester an obligation of 1,00o lion dollars that was in the hands of the Venetian consul, Luca Cortazzi (under whose jurisdiction Ferrieri fell), and represented Ferrieri's debt to Dirk Knipping. ${ }^{167}$ Forêt was hoping that the sequester would help him to reclaim the money he was still owed. For Knipping, the manoeuvre came as a surprise. He knew that di Panaiotis had been looking after Forêt's interests in Izmir, and on 2 October 1773, he received di Panaiotis' permission to travel to Holland on a voyage to settle his remaining debts with Forêt, his last remaining creditor. ${ }^{168}$

The same day, Knipping endorsed the obligation of 1,00o lion dollars to his Greek wife, Marigo Sottira, so she could use it in his absence. The action was defended as a consequence of the marital contract made between the husband and wife in 1758 . Two months later, di Panaiotis petitioned the French consul to place a sequester but still allowed Knipping to travel to Holland. Because he also accepted Knipping's latest repayment to Forêt, Knipping did not understand the actions of di Panaiotis. ${ }^{169}$ Two weeks after the sequester, Marigo Knipping obtained a promise from the Venetian consul to pay her the 1,000 lion dollars of the obligation in his hands. But for that purpose, the sequester needed to be relieved. In January 1774, Marigo petitioned Dutch consul Daniel Jean de Hochepied to request that his French colleague lift the sequester. ${ }^{170}$ The same day, di Panaiotis delivered a bundle of paperwork to the Dutch chancery with all the documents concerning the case between Pietro Ferrieri \& $\mathrm{C}^{\circ}$ and Dirk Knipping. These concerned all the information on the transactions involving Jacques Forêt. ${ }^{171}$ When the French consul confronted him with the

${ }_{167}$ As part of the larger obligation of 2,700 lion dollars. NACs, $\mathrm{N}^{\circ} 357$ ('Affairen tusschen Pietro Ferrieri \& Dirk Knipping'), 'Request van Dirk Knipping teegens Manuel Kiriako di Panajottis', Izmir, o7/o2/1774. A short biography of Charles de Peyssonnel (1700-179o), born in Marseille, can be found in John Aikin, Thomas Morgan, and William Johnston, General biography; or, lives, critical and historical, of the most eminent persons of all ages, countries, conditions, and professions, arranged according to alphabetical order (London, 1813), 8: p. 109. His son succeeded him as consul.

168 Dirk Knipping explicitly mentioned that such permission was needed, considering the agreement made between himself and Forêt. NACs, $\mathrm{N}^{\circ} 357$, 'Request van Dirk Knipping teegens Manuel Kiriako di Panajottis', Izmir, o7/o2/1774.

169 NACS, $\mathrm{N}^{\circ} 357$, 'Request van Dirk Knipping teegens Manuel Kiriako di Panajottis', Izmir, o7/ O2/1774.

170 NACS, $\mathrm{N}^{\circ} 357$, 'Request van Marigo Knipping aan den wel ed Graaf de Hochepied om door de Franse consul te laate intimeeren aan Man K: di Panajottis \& Comp.a om de sequestro te ontlossen', Izmir, 19/o1/1774.

171 NACs, $\mathrm{N}^{\circ} 357$, 'Recief van my can aen M.K. di Panajottis weegens een verseegelde plicq papieren aengaende de affairen tusschen Pietro Ferrieri \& Dirk Knipping', Izmir, 22/o1/ 1774 . 
request, di Panaiotis agreed to lift it, but only if the Dutch consul was willing to pay a caution, which he refused. ${ }^{172}$ Dirk Knipping, in the meantime, had informed the French consul, as well as a number of di Panaiotis' friends, that, if the latter refused to relieve the sequester, Knipping, whose clothes had already been transferred aboard a Dutch vessel, found himself obliged to declare bankruptcy, which would harm Forêt's interests as sole remaining creditor. ${ }^{173}$

Marigo Knipping's claim to lift the sequester, made on 19 January 1774 to de Hochepied, was the start of a trial that would be sentenced by the French consul. She and her husband had now become plaintiffs against the defendant Manolaki di Panaiotis, who, as a French protégé, fell under their jurisdiction. This was confirmed in the formulation of the sentence handed down by the French consul and his deputies a month later. ${ }^{174}$ At first sight, it might seem remarkable that much of the trial's paperwork is preserved in the Dutch consular archives, considering the case was tried before the French consul. But on closer inspection, it can be understood as an expression of the procedural pragmatism that existed in the adjudication of international disputes. All European nations had accepted forum rei, so nobody disputed that di Panaiotis should defend himself before a French court. But the plaintiffs did not need to appear physically before the same court. The French consular adjudication, like the Dutch one, followed summary procedure, which stipulated that the core of the trial was formed by written statements, replies and counter-replies. Similar to the Dutch assessor system, the French adjudicated their disputes using a consular judge accompanied by a number of the most important French traders. ${ }^{175}$

172 NACs, $\mathrm{N}^{\circ} 357$, 'Risposta di Manuel K: di Panaiottis dimandando cauzione all console di Ollanda p soltare il sequestro fatto a Dirk Knipping', Izmir, o3/o2/1774.

173 NACs, $\mathrm{N}^{\circ} 357$, 'Request van Dirk Knipping teegens Manuel Kiriako di Panajottis', Izmir, o7/ o2/1774; and 'Versoekschrifft van Dirk Knipping om in de Franse cancel: te nottificeeren dat sijne conventie vernieuwd met Jacques Forret om in tien jaaren alles te betaelen, dog inteegendeel staende blijvende hij daer toe niet in staat was \& alles moeste abandonneeren', Izmir, 19/02/1774.

174 NACs, $\mathrm{N}^{\circ} 357$, 'Sentenza van de heere Franse consul \& gedeputeerdens weegens de gesequestreerde Lx10oo van Dirk Knipping onder de heere Venetiaanse consul', Izmir, 21/o2/ 1774 .

175 For more on the French consuls, with specific attention paid to the Levant, see Anne Mézin, Les consuls de France au siècle des lumières (1715-1792) (Paris, 1997); see also the essays on French consuls by Jörg Ulbert, 'La dépêche consulaire française et son acheminement en Méditerranée sous Louis XIV (1661-1715)', pp. 31-57; Julien Sempéré, 'La correspondance du consulat français de Barcelone (1679-1716). Informer comme un consul ou comme un marchand?', pp. 121-140; and David Plouviez 'Puissance navale et réseaux consulaires. L'action des consuls français en Italie et sur les marges occidentales de l'Empire ottoman au XVIIIe siècle', pp. 179-199; all in Les consuls en Méditerranée, agents d'information XVIe-XXe siècle, ed. Silvia Marzagalli (Paris, 2015). 
The plaintiffs, who fell under Dutch jurisdiction, were not forced to submit their documents to the French court. They were allowed to submit everything at the Dutch consulate, and in their statements, they specifically addressed the Dutch consul to inform his French colleague. When Marigo Knipping filed her claim, an additional paragraph added by the consul instructed the chancellor to keep a copy of it in the chancery and to send another copy to the French chancellor, 'asking them to do justice and to instruct Manolaki di Panaiotis to relieve the sequester and to condemn him to reimburse all expenses and interests. ${ }^{176}$ Di Panaiotis was doing the same but the other way around - he addressed the French consul. The only exception was that he had deposited some relevant paperwork concerning Forêt's transactions with Knipping and Ferrieri to the Dutch chancery.

This was a practice that created additional paperwork, as more copies needed to be made, and some of them might need additional translations. Knipping wrote in Dutch and di Panaiotis in Italian. Consul de Hochepied was also able to communicate in Italian, as was Knipping's wife. The French consul issued his documents in French. In disputes, the chancellor's task was to inform litigating parties of any statements filed by the opposition - this did not change - but an additional layer was created as it was not the Dutch chancellor but rather the French chancellor who would inform di Panaiotis of this in person. When visiting a litigant, the chancellors were often accompanied by witnesses. Sentencing, of course, was still the prerogative of the consular court of the defendant. In this case, the legal dispute was about the sequester that di Panaiotis had made through the French consul. Since 1686, a Dutch regulation existed that dealt with sequesters on goods in the Levant, but obviously, it did not directly cover the problem of an Ottoman merchant who was a French protégé laying a claim on monies in the hands of the Venetian consul, covering a debt of a Venetian subject (in partnership with an Englishman) to a Dutch subject and endorsed to that subject's Greek wife, in order to seek satisfaction for an outstanding debt the Venetian had with an inhabitant of Liège from a sale concluded by the Dutchman years earlier. With so many international parties, it might be considered remarkable that at no moment was competence or jurisdiction questioned. It was evidently a matter of French jurisdiction. Di Panaiotis laid out his arguments to the French consul and Dirk and Marigo

176 NACs, $\mathrm{N}^{\circ} 357$, 'Request van Marigo Knipping aan den wel ed Graaf de Hochepied om door de Franse consul te laate intimeeren aan Man K: ${ }^{\circ}$ di Panajottis \& comp.a om de sequestro te ontlossen', Izmir, 19/o1/1774, '[...] pregandola di fare giustizia \& di ordinare a Manolaki di Panaiotis di levare il sequestro \& di condannargli all'rifarcimento d'ogni danno spese x intresse $[\ldots]$ '. 
Knipping before the Dutch one. The consuls were in contact through their chancellors but also talked in person. ${ }^{177}$ At a certain moment, Pietro Ferrieri was demanded to appear before both the Dutch and Venetian consuls, declaring that the 1,00o lion dollars in Cortazzi's hands arose from a debt Ferrieri owed Knipping for 400 lion dollars-worth of gunpowder and 600 lion dollars of cash. ${ }^{178}$

In his written reply to Dirk Knipping's summary of the case on 7 February, in which he restated his wife's claim to lift the sequester, Manolaki di Panaiotis mentioned he felt that Knipping had made an unreasonable threat, trying to claim money that did not belong to him in order to give it to his wife. ${ }^{179}$ After receiving di Panaiotis' reply, the consul ordered his chancellor, Mann, to notify Dirk Knipping, as the French chancellor had asked. Mann went to Knipping's house that same day in the company of two witnesses. Knipping replied that he had nothing more to add, and he wanted the French consul to reach a verdict. ${ }^{180}$ His wife must have known that the sentence would go against her and her husband, as on 23 February she issued a power of attorney to Gasparo Giovanelli to further look after her interests concerning the obligation and to interact on her behalf with 'justice, magistrate, tribunal and court'.181 She did so because she argued that, as a woman, she was not a legally independent person. ${ }^{182}$ She was well-informed, because later that day, the sentence of French Consul Charles de Peyssonnel was submitted to the Dutch chancery (the verdict itself had been pronounced at the French consulate on the twentyfirst). The French consul and four 'negocians notables de la nation, assistans en jugement' had analysed all the evidence, including Cortazzi's obligatory note and the two older ones that Ferrieri had given to Knipping for 2,039:50 lion dollars and 2,700 lion dollars to cover the sale of the 831 pairs of pistols. ${ }^{183}$ The

177 The documents contain additional written instructions from the consul to the chancellor, as well as comments from the chancellor concerning what he did, and when.

178 NACs, $\mathrm{N}^{\circ} 357$, 'Memorie van Dirk Knipping tot het giudiceeren zijner saeken', Izmir, 23/o2/ 1774 .

179 NACS, $\mathrm{N}^{\circ} 357$, 'Triplicq van M. K.co di Panajottis aan Dirk Knipping op zijn replicq', Izmir, 18/02/1774.

180 Ibid. The additional information also exists as a separate copy, NACs, $\mathrm{N}^{\circ} 357$, 'Copia dell decreto dall illmo Hochepied su la supplica dall sigr Manolaki Kiriako di Panaiotis toccando la pretensione in riguardo dell seguestro di Lxıooo in mane dall Luca Cortazzi console Vento', Izmir, 18/02/1774.

181 NACS, $\mathrm{N}^{\circ} 357$, 'Procuratie van Marigo Knipping in faveur van Gaspero Giovanelli', Izmir, $23 / 02 / 1774$, ' $[\ldots]$ giudizio, magistrate, tribunale e corte [...]'.

182 Ibid.

183 NACS, $\mathrm{N}^{\circ} 357$, 'Sentenza van den heere Franse consul \& gedeputeerdens weegens de gesequestreerde Lx 1000 van Dirk Knipping onder den heere Venetiaanse consul data 
French consular court had also investigated declarations by Gerrit van Brakel (who was not an involved party here and thus addressed his statement directly to the French consul), Cortazzi and Carlo Mudiano, the Venetian chancellor. The French consul and his assistant-judges decided that the obligation in the hands of Luca Cortazzi for 1, ooo lion dollars did not belong to Marigo Knipping but to her husband Dirk, and it was part of the payment for the transaction of the $83^{1}$ pairs of pistols that belonged to Forêt. This meant Marigo's request to relieve the sequester was denied. Dirk Knipping's argument about his payment plan with Forêt was also not relevant considering the sequester was made to recover debts from Ferrieri, which were separate from the agreement between Knipping and Forêt. Forêt was still owed money that was rightfully his, and the sequester was maintained. ${ }^{184}$

Knipping, who had been at the consul's house on the day of the verdict was very disappointed by the outcome and convinced that Charles de Peyssonnel had been partial. He also objected that Ferrieri's obligations had been subjected to examination by men belonging to a different nation while he had not been allowed to see them. He argued that a mistake had been made. It seems that the French sentence suggested that Ferrieri paid Knipping more than he actually had, and this suggestion created the misunderstanding about the obligation in the hands of Cortazzi. That obligation consisted of a debt of Ferrieri, which Ferrieri had admitted, but for money that Knipping insisted belonged to his wife. Knipping reminded the Dutch consul that his wife had declared as much under oath to 'her confessor', and she was willing to do that again. ${ }^{185}$

Confronted with the French sequester, Knipping entered a bankruptcy procedure before the Dutch consular court, as he was a Dutch subject. It must have been a blow for Knipping, who had almost managed to overcome his earlier financial difficulties. He offered his balance sheets to the consul, as the competent magistrate, who proceeded 'according to the law and laws in our [the United Provinces] lands.'186 First, privileged debts were to be paid that were related to the dowry, doctor's bills and maid's wages, after which the remaining creditors were to be reimbursed as much as possible following a public sale of

21 feb: 1774 \& geremitteerd in deese Neederlandse cancellerij heeden namiddag 23 feb:', Izmir, 21/02/1774.

184 Ibid.

185 NACs, $\mathrm{N}^{\circ} 357$, 'Memorie van Dirk Knipping tot het giudiceeren zijner saeken', Izmir, 23/o2/ 1774 .

186 NACs, $\mathrm{N}^{\circ} 357$, 'Ordinantie van den heere Consul Daniel Jan Graaf De Hochepied tot het verseegelen \& opneemen p.r inventaris der meubelen \& inboedel van Dirk Knipping', Izmir, 22/o2/1774, '[...] volgens regt $\mathrm{x}$ wetten onser landen $[\ldots]$ '. 
Knipping's goods. ${ }^{187}$ In February 1774, the consul ordered the chancellor to seal Knipping's home, make an inventory of his goods and inform the creditors to appear the next day at ten o'clock at the consular house so curators could be chosen. Chancellor Mann went to several houses, including those of some of Knipping's Greek creditors, of which several did not consider it necessary to appear, claiming to accept all the magistrate's decisions. Somewhat ironically, Mann also paid a visit to Marigo Knipping, whose marital contract made her one of her husband's creditors, and she replied that she, as 'a woman in these Turkish lands, could not represent herself', so she would send one or two men in her stead - repeating what she had claimed earlier. ${ }^{188}$

The Knippings were not finished, as the fact that Marigo was her husband's creditor led her to request preferential payment out of Knipping's effects - to satisfy the debt arising out of the dowry - under the reasoning that 'women had a more particular right to public protection.' ${ }^{189} \mathrm{Her}$ argument, specifically addressed to Consul de Hochepied, was both legal and emotional, the latter not uncommon but the former more so, as her specific legal tone did not occur all that frequently amongst litigating merchants. She did not mention any particular law but instead spoke about 'the sanctity of the law' and the 'maximum of consecrated jurisprudence from the authority of so many illustrious legislators' amounting from 'a constant practice going back many centuries'. ${ }^{190}$ She found it ridiculous that di Panaiotis continued to refuse to relieve the sequester without having heard from Forêt, as 'he wasn't the emperor of the moon'.191 She felt it was rather the competent magistrate, Dutch Consul de Hochepied, who had to decide on it as 'custodian, vindicator and organ of the law'. 192 She concluded by stating that the superiority of de Hochepied's talents and the goodness of his heart unified the most sacred commitment to justice and the defence of oppressed innocence. ${ }^{193}$

187 For both the system of privileged debts and the dowry, see p. 204.

188 NACS, $\mathrm{N}^{\circ} 357$, 'Ordinantie van den heere Consul Daniel Jan Graaf De Hochepied tot het verseegelen \& opneemen p.r inventaris der meubelen \& inboedel van Dirk Knipping', Izmir, 22/02/1774, '[...] als eene vrouw insonderheid in dese Turkse landen in haere persoon niet konde compareeren [...]' The same day an inventory was made.

189 NACS, $\mathrm{N}^{\circ} 357$, 'Suplicq van Marig: Knipping tot versoek van betaeling bij preferentie uijt de boedel van haar man', Izmir, 24/o2/1774, '[...] che le donne hanno un diritto più particolare alla prottezione pubblica $[\ldots]$ '.

190 Ibid., ‘[...] la santità delle leggi $[\ldots]$,', ‘[... l'massima di giurisprudenza consacrata dall'autorità di tanti illustri legislatori [...]' and '[...] dalla prattica constante di tanti secoli [...]'.

191 Ibid., '[...] l'imperator della luna [...]'.

192 Ibid., '[...] il custode il vindice e l'organo delle leggi [...]'.

193 Ibid. 
While Marigo Knipping's argument did not really entail a questioning of jurisdiction, as she opposed di Panaiotis before the Dutch consul, it does point to the intermingling of cases under different jurisdictions - di Panaiotis' French sequester and Knipping's Dutch bankruptcy. Not surprisingly, her petition can be considered an attempt to make the sequester subordinate to the bankruptcy. The passion in her language might have represented a desperate final plea to the consul, but emotion was regularly present in legal reasoning, and in that sense, Marigo Knipping's petition was not exceptional. ${ }^{194}$ Her request was neither without precedent nor without legal foundation. Dutch law contained stipulations on the privileged status of the dowry, and in Italy, wives could become creditors of their husbands' estates. ${ }^{195}$ De Hochepied appointed two curators, Esaias Fercken, a merchant from Liège who had arrived in Izmir to work as a scribe in the Dutch firm of Clement \& van Sanen (see table 3), and Gasparo Giovanelli, a Venetian physician who had also received power of attorney from Marigo Knipping to defend her interests regarding the 1,ooo lion dollars. ${ }^{196}$ In their report, they stated that Knipping was indebted for a total sum of 3,664:61 lion dollars but still was due 1,448:44 lion dollars, mostly from Luca Cortazzi, but which also included another 300 lion dollars he was owed by Ferrieri. Giovanelli and Fercken confirmed the preferential status of Marigo as a creditor, closely followed by the claims of the domestic servants, and they demanded that the Dutch consul contact the French consul in order to remove the sequester and that the Venetian consul make Ferrieri pay his 300 lion dollars. ${ }^{197}$ Ferrieri declared he would not pay unless the sequester on Cortazzi's 1,0oo lion dollars was relieved, while di Panaiotis maintained that Knipping had not been forced to declare bankruptcy. He insisted that the sequester had been legitimate and that the money was not Marigo's, contrary to what she and her husband had declared. ${ }^{198}$ The situation, in short, remained the same, and the archives do not contain any hint about its final resolution.

194 For emotion in litigation, see pp. 185-188.

195 Julius Kirschner, 'Wives' claims against insolvent husbands in late medieval Italy', in Women of the medieval world: Essays in honor of John H. Mundy, eds. Julius Kirschner and Suzanne F. Wemple (Oxford, 1985), pp. 256-304.

196 NACs, $\mathrm{N}^{\circ} 357$, 'Procuratie van Marigo Knipping in faveur van Gaspero Giovanelli', Izmir, 23/o2/1774; and 'Sententie van den Hr Consul om te noemen 2 curatorij, den hr doctor Giovaneli \& Ferken, op de zaaken van Dirk Knipping', Izmir, o3/o3/1774.

197 NACs, $N^{\circ} 357$, 'Request van sig: Giovanellj \& Esaias Ferken tot versoek van ontslag der gelden van Knipping bij den heere Venetiaanse consul in beneficie van geprivil schuld aen de huysvrouw Marigo Knipping', Izmir, o5/03/1774.

198 NACs, $\mathrm{N}^{\circ} 357$, 'Antwoord van Pietro Ferrieri op de vraag der ssr curateuren van Dirk Knipping der bewuste Lx 300 in handen van Ferrierj adj 11/03/1774 ontf in deese Nederlandse can: \& overgegeeven aen den heere consul Graaf Hochepied', Izmir, 11/o3/ 
After 1774, the name Dirk Knipping no longer comes up in the consular archives. He voluntarily abandoned the position of tax overseer in January 1774, to be replaced by the man who had acted both as plaintiff against him as well as representative on behalf of him, Gerrit van Brakel. ${ }^{199}$ In November 1795, a newspaper mentioned his death from the plague in Izmir, 'where he had lived for forty years', as well as the death of the widow of van Sanen. ${ }^{200}$ Di Panaiotis' quarrels with Dutch merchants were far from over, and he reappeared later, when he denounced a former business partner, Jacob de Vogel, as someone who shipped goods from Ottoman merchants under his own name, an infraction of the national oath and a fraud against the payment of taxes. $^{201}$

Although the final sentence in the case of Knipping, Forêt and Ferrieri three subjects of different nationalities - remains unknown, complex trials such as this one, undertaken at the Dutch and French consular courts, are extremely useful for scholars as they show several things. The nature of Levant trade caused regular intercultural and international transactions. When something went wrong, it might lead to the involvement of the authorities and the justice systems of several European nations and potentially also of Ottoman justice. The references in the documents preserved at the Dutch consular court of Izmir make it clear that the French, Dutch and Venetian consuls all had their say on the case at hand. They used their abilities to sequester monies on behalf of their own subjects, and they were all part of the procedural aspects of the case through the involvement of the Venetian, Dutch and French chanceries. While litigants only rarely, if ever, raised a complaint about a court's jurisdiction, the involvement of various jurisdictions did bring Knipping to vent complaints about partiality, perhaps hoping for Consul de Hochepied's partisanship. ${ }^{202}$

The trial had been initiated to satisfy the claims of a man who was not Dutch, French or Venetian and who resided thousands of kilometres away

1774; and 'Antwoord van Manuel K: ${ }^{\circ}$ di Panajottis op de vraag der h:n curateuren van Dirk Knipping der bewuste Lx 1000 in handen van den h:r venetiaanse consul Luca Cortazzi', Izmir, 14/o3/1774.

199 NACS, ${ }^{\circ} 357$, 'Acte van eed van Gerrit van Brakel als opsiener aenden toll vande Nederlandse natie in Smirna', Izmir, 20/o1/1774; see also Heeringa and Nanninga, Bronnen tot de geschiedenis, 4: p. 191, 'Extra-ordinaris vergadering van de directeuren met de buitenleden te Amsterdam', 26/10/1774.

200 De Generaliteits-courant, $07 / 11 / 1795$, , [...] er 40 jaaren gewoond heeft [...]'.

201 See pp. $283-285$.

202 NACS, $\mathrm{N}^{\circ} 357$, 'Memorie van Dirk Knipping tot het giudiceeren zijner saeken', Izmir, 23/o2/ 1774 . 
from Izmir and probably never had set foot in the Ottoman Empire - Jacques Forêt from Liège. For Forêt, the system worked, and rulings at both the Dutch and French courts were in his favour, although it remained complicated to obtain financial satisfaction from a merchant far away, particularly as both his agent - Dirk Knipping - and at least one of his clients - Pietro Ferrieri - had financial troubles. But it is important to note that the consul's verdict was not based on a favourable approach towards the defendant, a Dutch national, who held an official position at the consulate and who had been living in Izmir for eight years. For de Hochepied, respecting commercial custom, as confirmed by a variety of other traders, was more important, as it was this attitude that held together the Europeans' system of trade in the Levant. The call to perform justice was the same, whether it was uttered at the Dutch or the French consular court, and cases were adjudicated by a mixture of peers, as both French and Dutch merchants had a voice in the final verdict of their respective consular courts, and of diplomats who, in the case of the United Provinces and France, were not allowed to engage in business, a situation which was very different from their English and Venetian counterparts. ${ }^{203}$

The role merchants played in the legal decision-making process at both the French and Dutch consular courts confirms the importance given to mercantile customs, as its legal application was best guaranteed through the involvement of those who understood it best, the traders, not simply as expert witnesses, although this occurred regularly, but as co-judges. None of the cases studied provide any support for the thesis that litigating traders had any problem with the involvement of colleagues, who were potential competitors, in their trials. Their competence was never questioned; Knipping only expressed his frustration about foreign merchants looking at obligatory notes he was not allowed to see. Jacques Forêt also needed to rely on the merchants' style, not only in his business dealings in Izmir but also when he felt forced to summon some of the merchants he had been dealing with in court. The commercial trust he placed in his middlemen had failed to protect him from trouble. He now had to hope his legal trust in first a Dutchman and then a Greek Ottoman trader would serve him better. He also would have to rely on the impartiality and expertise of the Dutch and French consular jurisdictions in Izmir, which might have been the biggest leap of faith of all. Commercial trust was constantly evaluated through reputational mechanisms upheld by the merchant community itself. The same

203 The French consuls often originated from established families in Marseille, which guaranteed a good understanding of French Levant trade, but they were not merchants themselves. Masson, Histoire du commerce, p. 447. 
mechanisms applied when a trader was asked to protect a peer's interests in court. He had at least as much to offer to Dirk Knipping as Knipping to him, and Knipping risked, by not taking Forêt's interests to heart, losing an important commission, as well as other commissions from Liège and Rotterdam and perhaps elsewhere in the future. Similar mechanisms applied to ensure the best efforts of the traders he had provided with a power of attorney. A lack of effort by van Brakel or di Panaiotis in court would harm their reputations as traders as well, as no distinction was made between pursuing the best interests of a principal in trade or in court.

Forêt might have been less sure about the quality of the Dutch and French courts. He did not fall under their direct jurisdiction, and consuls were specifically expected to defend national interest. In that light, it is perhaps not a coincidence that, in a Dutch trading community that was dominated by Amsterdam traders and which maintained a strong connection with the Directorate of Levant Trade in Amsterdam, Jacques Forêt had first chosen Gerrit van Brakel to represent him, a trader who had come from Rotterdam, and later Manolaki di Panaiotis, who was a Greek Ottoman but who had formed an earlier association in Izmir with a merchant from Rotterdam, Jacob de Vogel. They might have had less to share with Knipping, and furthermore, Forêt had good connections in Rotterdam, which he also had visited personally. One of his main correspondents there, Herman van Coopstad, had been a director of Levant trade in Rotterdam since 1745 - and the directorate there was known to compete with their Amsterdam counterpart. His reliance on merchants from a relatively small circle in Rotterdam might have had as much to do with his familiarity with merchant circles there as with his fear that, in court, Amsterdam traders might protect each other too much from claims issued by the outsider Jacques Forêt.

\subsection{Invoking 'National' Law versus the Merchants' Style}

Solving a dispute regarding commission trade was common but could also be complicated because of the distance between litigants. The cases tried at the Dutch consular court that were concerned with a dispute between principals and their agents at times involved non-Dutch principals, such as Jacques Forêt. A non-Dutch agent rarely appears amongst the defendants tried at the Dutch consular court in Izmir, and if he did, it meant he was either an Ottoman holding a berat or a European belonging to one of the nations for which the Dutch consul officially acted as a diplomatic representative. Because European consulates allowed for litigating parties to file their documents at the chancery of their own consulate, the Dutch consular archives do contain a few documents related to court cases adjudicated by another European consular court, 
such as the dispute that arose between the Amsterdam-based firm of Weduwe Offerman \& $\mathrm{C}^{\circ}$ (Widow Offerman \& $\mathrm{C}^{\circ}$ ) and the firm of André Chabeaud in Izmir. In June 1772, the Offerman firm sent four bales containing forty sheets of cloth to André Chabeaud, a French merchant in Izmir and agent for the house of Blanchenay \& $\mathrm{C}^{\circ}$ in Marseille. ${ }^{204}$ The Offerman firm had been put in contact with the Frenchmen through a mutual acquaintance, and the cloth served as sample, to see what Blanchenay and their agents, the firm of André Chabeaud, would be able to achieve. The Offerman firm confirmed with Blanchenay that they hoped to send more parcels in case the first sample fetched a good price, and they concluded their first letter by stating that 'it shall be very pleasant for us, if we could conduct some business that is useful for both sides, from time to time'. ${ }^{205}$ The Blanchenay firm expressed their happiness about the recommendation from their mutual friend and also hoped the first contact would lead to more: 'should we be able to serve you here or in another place, it would be most pleasurable to us, we do not only trade in Izmir, we also deliver many commissions for your lands, and friends there [the United Provinces] send us spices and other wares to sell.'206

It is not clear whether the Offerman firm had particular reasons for choosing a French intermediary beyond the recommendation they had received, but the choice meant that they accepted the possibility of French adjudication in case something went wrong. It seems that it was their first attempt at Levantine trade, so they might not have known any Dutch agents in Izmir. The Offerman firm probably sent the sample in an attempt to expand its business following the recent death of Pieter Offerman, head of the firm. In January 1772, an article in an Amsterdam newspaper informed its readers that the firm of Pieter

204 French Levant trade was a monopoly of trading houses in Marseille that all had their representatives in Levantine échelles. This meant that in contrast to the Dutch merchants in Izmir, their French colleagues were all working for firms in Marseille. See chapter one. NACs, $\mathrm{N}^{\circ} 354$ ('André Chabaud \& $\mathrm{C}^{\circ}$, Franse kooplieden te Smyrna, tegen Daniel Fremeaux \& $\mathrm{C}^{\circ}$, optredend namens de weduwe Offerman \& $\mathrm{C}^{\circ}$ te Amsterdam, 17721773'), 'Wed: Offerman aen Blanchenay, Paul \& C ${ }^{\circ}$ a Marseille', Amsterdam, 18/o6/1772. The actual document that has been preserved is a copy made on 15/10/1772.

205 NACs, $\mathrm{N}^{\circ} 354$, 'Wed: Offerman aen Blanchenay, Paul \& $\mathrm{C}^{\circ}$ a Marseille', Amsterdam, 18/o6/ 1772 , ' [...] zal het ons zeer aangenaam weezen, indien wy in vervolg van tyd aanzienlyke en voor weerskanten nuttige affaires met elkanderen konden doen [...]'.

206 NACs, $\mathrm{N}^{\circ} 354$, 'Blanchenay Paul \& $\mathrm{C}^{\circ}$ aan hrn wed Pet Offerman \& $\mathrm{C}^{\circ}$, Marseille, o3/o7/ 1772. The actual document that has been preserved is a copy made on $15 / 10 / 1772$, ' [...] indien wy u ed in het eene of andere hier ter plaatze zoude konnen dienen, dit zou ons zeer aangenaam weezen, behalve onzen handel in smirna bezorgen wy veele comissies voor costige gewesten, en costige vrienden zenden on sook specereyen en andere waaren ter verkoop $[\ldots]$ '. 
Offerman \& Zoonen, trading in Amsterdam and Imgenbroich near Aachen in Germany, was dissolved, and its business would be continued by two separate firms, the Weduwe Offerman \& $\mathrm{C}^{\circ}$ in Amsterdam and Franz Pieter Offerman in Imgenbroich. ${ }^{207}$ It was perhaps the new firm's inexperience in Levant trade that contributed to the fact that something did indeed go wrong. They had not sent the four bales themselves but had used an intermediary for the shipping named Philip Ludwig Bernhard, a trader also based in Amsterdam. Bernhard was the man who convinced them to use Chabeaud, Blanchenay's agent, as the intermediary for the transaction, as Bernhard and Blanchenay were friends in business. The latter expressly asked Bernhard to find clients they could get commissions for in the United Provinces. ${ }^{208}$

Unfortunately for all involved, Bernhard declared bankruptcy a few months after the shipment, and Blanchenay was one of his creditors. Offerman's problem arose from the fact that Bernhard had not specified to Chabeaud that the cloth belonged to Offerman. This meant that the merchandise was considered Bernhard's, and Offerman was running the risk of losing it. When they found out about Bernhard's bankruptcy, the Offerman firm petitioned the States General in the hopes of recuperating their goods, following legal advice given to them by specialists. ${ }^{209} \mathrm{~A}$ declaration written by Bernhard, who confirmed that he had indeed expedited Offerman's goods to Izmir and not his own, was included in the petition. ${ }^{210}$ The States General were sympathetic towards the petition and agreed to send the Dutch consul in Izmir instructions 'to offer a helping hand as much as possible'.211 He was asked to contact his French colleague and to ensure either the recuperation of the cloth or the profits if they already had been sold. ${ }^{212} \mathrm{~A}$ copy of the resolution issued by the States General, as well as copies of Offerman's request, Bernhard's declaration, an account of the shipment and extracts from correspondence exchanged between Blanchenay and Offerman were all sent to the Dutch consulate in Izmir. The shipped documents also included a power of attorney

\footnotetext{
207 Amsterdamsche courant, 21/01/1772.

208 NACs, $\mathrm{N}^{\circ} 354$, 'Blanchenay Paul \& $\mathrm{C}^{\circ}$ aen hrn wed Pet Offerman \& $\mathrm{C}^{\circ}$ ', Marseille, o3/o7/ 1772.

209 NACS, $\mathrm{N}^{\circ} 354$, 'Request voor de wed P Offerman en $\mathrm{C}^{\circ}$, Amsterdam, 13/10/1772, '[...] door advisen van rechtsgeleerden $[\ldots]$...

210 Ibid.

211 NACS, $\mathrm{N}^{\circ} 354$, 'Extract uit het register der resolutien van de ho mog heeren Staten Generaal der Vereenigde Nederlanden', The Hague, 13/10/1772, '[...] zoo veel mogelijk de behulpsaame hand te bieden [...]'.

212 Ibid.
} 
given to Daniel Fremeaux \& $\mathrm{C}^{\circ}$ in Izmir, a Dutch firm who was to represent Offerman's claims there. ${ }^{213}$ The document specified that Fremeaux should 'seek justice if necessary, to arrest or sequester persons, monies and goods, to persist such sequesters and to lift them, to appear before all tribunals, courts and justice chambers, to observe all legal terms, and to request verdicts and sentences and their execution, as well as to appeal disadvantageous sentences'.214 In December 1772, Fremeaux filed an official petition with the Dutch consul to demand payment from Chabeaud through the French consul, a letter that was written in Italian, like all of their subsequent written statements. ${ }^{215}$ Fremeaux's petition started the procedure with Offerman as plaintiff and Chabeaud as defendant - meaning it was adjudicated by the French consul, Claude-Charles de Peyssonnel.216

Chabeaud was instructed by the French consul to reply to Fremeaux's statements, and he answered that Offerman's merchandise had already been sequestered following a sentence issued by the consular judges in Marseille at Blanchenay's behest to claim outstanding debts from Bernhard. This information was confirmed by the French consul. ${ }^{217}$ Fremeaux remained in contact with the Offerman firm, which sent him an official casuspositie written by attorneys in Amsterdam in April, affirming the claim of the Offerman firm as proprietors of the goods and relying on Roman law as described in the Hollandse Consultatien and the work of van Leeuwen, an authority on DutchRoman law. ${ }^{218}$ The recourse they sought to Dutch written law in a matter of sequester and bankruptcy is in itself not surprising, as it was one of the few

213 Fremeaux, born in 1714, was an important man, who had been assessor since 1752, a function he retired from in 1795, the year in which he died.

214 NACS, $\mathrm{N}^{\circ} 354$, 'Verklaring voor notaris Nathanael Wilthuijzen \& getuijgen', Amsterdam, 19/ $10 / 1772$, ' $[\ldots]$ desnoods regt te plegen, persoonen penningen en goederen te arresteeren dezelve arresten te vervolgen en na geraden wederom ontslaan, voor alle Hoven, geregten en kameren van Justitie te compareeren, alle termynen van regten te observeeren, vonnissen en sententien te versoeken obtineeren executeeren off van de nadelige te appelleeren $[\ldots]$ '.

215 NACS, $\mathrm{N}^{\circ} 354$, 'Request van D: Fremeaux \& $\mathrm{C}^{\circ}$ tot versoek om aen de Franse consul te versoeken om Chabaud \& $\mathrm{C}^{\circ}$ te constiengeeren tot betaeling van het rend: van 4 pakken laeken intrest van de wed: Pieter Offerman \& $\mathrm{C}^{\circ}$ d'Amsterdam', Izmir, o9/12/1772.

216 Son of the previous consul, Charles de Peyssonnel. For Claude-Charles, see Pierre Larousse, Grand dictionnaire universel du XIXe siècle (Paris, 1874), 12: p. 740.

217 NACs, $\mathrm{N}^{\circ} 354$, 'Antwoord van André Chabaud \& $\mathrm{C}^{\circ}$ aen D: Fremeaux weegens 4 pakken laakenen van de wed: $\mathrm{P}$ Offerman \& $\mathrm{C}^{\circ}$ d'Amsterdam ter deeser Nederlandse cancell: ontfangen op heeden $15 x$ ber en aen de heeren D: Fremeaux \& $\mathrm{C}^{\circ}$ g'intimeert op 16 ditto anno 1772', Izmir, 15/12/1772.

218 NACs, $\mathrm{N}^{\circ} 354$, 'Casus positie', Amsterdam, o2/o4/1773. A casuspositie was a declaration on the case by peers; see also p. 110 . 
types of commercial disputes for which written law existed. ${ }^{219}$ Sequesters and bankruptcies, however, were not uncommon amongst merchants, and this document, containing the opinion of professional attorneys on a commercial dispute, is the only one of its kind found in the archives of the Dutch consulate of Izmir, contrary to the much more frequent use of reports signed by other merchants confirming commercial usage and custom. The rarity of the presence of such documents seems surprising considering the ease with which both the States General and the Dutch consul offered support to Weduwe Offerman \& $\mathrm{C}^{\circ}$.

Perhaps the Offerman firm wanted more than a reliance on mercantile custom, considering they were far away, and the merchant holding their power of attorney had to argue their case by submitting written statements to a foreign consulate. ${ }^{220}$ It is perhaps telling of the minor importance of written law in settling international trade disputes, in comparison to the role of the merchants' style, that the arguments brought forward by Fremeaux did not impress Chabeaud at all. On the contrary, he replied that the sequester and the French verdicts 'had been based on reason and equity and had been expressed in the most honest words, and that it was a truth that all the emphasis and bloatedness of the Italian language would not be able to destroy'221 Fremeaux had shown a document from Amsterdam that explained the legal fairness of Offerman's claim in terms of Dutch-Roman law, which theoretically could be recognised by the French litigants through ius commune, but Chabeaud \& $\mathrm{C}^{\circ}$ answered by referring to simple reason. Chabeaud \& $\mathrm{C}^{\circ}$ 's letter ended with an explicit refusal to reply to any further statements Fremeaux might make. They equally refused to let Fremeaux see any of their business documents. ${ }^{222}$ Chabeaud's strong stance is particularly interesting in this case, as it seems his argument was that Fremeaux had relied on national Dutch written law in an attack on the French and had thus violated the merchants' style, which was based on reason and equity in an international context and thus could not be applied within a national framework. It was almost indecent, it seems, to use

219 See pp. 199-208.

220 The combination of bankruptcy and the involvement of other European diplomats, for instance, led to considerations on written law; see pp. 199-208.

221 NACS, $\mathrm{N}^{\circ} 354$, 'Antwoord van Chabaud \& $\mathrm{C}^{\circ}$ weegens de in proces hangende 4 pakken laekens van de wed: Offerman \& $\mathrm{C}^{\circ}$ ', Izmir, 14/og/1773, 'Il etoit fondé sur la raison et l'equité et exprimé dans les termes les plus honnêtes, c'est une vérité que toute l'emphase et tout le boursonflage de la langue italienne ne sauroit detruire'.

222 Ibid. 
'national' arguments, such as a declaration drafted by attorneys in Holland and not by fellow merchants in Izmir, against a trader of a different nationality.

Chabeaud's argument resonated with the French consul and his assistantjudge, and after examining all the evidence that was brought over by the Dutch chancellor and the documents submitted with the French chancery, the French consular court sentenced against the plaintiff and in favour of the defendant, which meant the sequester was upheld. ${ }^{223}$ About a week after the sentence was issued, the Fremeaux firm issued an appeal against the verdict, which was registered at the Dutch consulate and presented at the French consulate the next day. ${ }^{224}$ The appeal was a natural consequence of the power of attorney they had received, but it remains unclear if the Offerman firm decided to proceed with it. Further adjudication would have taken place in Marseille, and the Offerman firm would have needed to send someone there or grant a power of attorney to a merchant established there. This turn of events was a risk the firm of Offerman, knowingly or unknowingly, had taken by employing French commissioners. The archives there do not contain any traces of further litigation, so it is impossible to say whether the Offerman firm really wanted to continue an appeal under French jurisdiction. ${ }^{225}$

Unlike what Jacques Forêt had done, the Offerman firm kept a close eye on proceedings in Izmir. While the final outcome of the dispute is not known, both the firms of Weduwe Offerman \& $\mathrm{C}^{\circ}$ and Philip Ludwig Bernhard went bankrupt after the case and deposited their accounts before the Desolate

223 NACs, $\mathrm{N}^{\circ} 354$, 'Sententie van den heere france consul de Peijssonnell in de differentie weegens 4 pakken Laekenen onder Cabaud \& $\mathrm{C}^{\circ}$ ', Izmir, 27/10/1773. For a discussion on the role of chanceries in formalizing commercial deeds in the context of early modern French consulates, see Arnaud Bartolomei, 'Actes notariés versus actes de chancellerie. Le rôle des chancelleries consulaires françaises dans la formalisation des actes commerciaux et civils (XVIII -XIXe siècle), Mélanges de l'École française de Rome - Italie et Méditerranée modernes et contemporaines, 128:2 (2016), consulted online at https:// journals.openedition.org/mefrim/28o1?lang=it.

224 NACS, $\mathrm{N}^{\circ} 354$, 'Acte van appel der heeren Fremeaux \& $\mathrm{C}^{\circ}$ in de differentie van 4 pakken lakenen van de wed: Offerman \& Comp:', Izmir, o5/11/1773.

225 The Archives Départementales in Marseille (ADM) contain a series of books in which legal deeds, claims and reports were registered, but no trace can be found of any litigation involving Offerman, Blanchenay and Chabeaud. The register for 1772 contains two reports on a dispute about a transaction of goat wool that involved André Chabeaud. ADM, XIII B 421, 'Verbaux et rapports divers' (1772), 'Rapport fait par les srs Vital Badere x Caurau Laina a la poursuitte detts Simon Lefleche $\mathrm{x}^{\circ}$ contre Chabaud \& $\mathrm{C}^{\circ}$, Marseille, 26/o9/1772 and ADM, XIII B 421, 'Raport de verification de 28 balles laine de chevron d les Belleville freres \& Chabaud negts de cette vills contre les André Chabaud \& $\mathrm{C}^{\circ}$ negts a Smirne', Marseille, 30/09/1772. 
Boedelskamer in Amsterdam, in 1784 and 1779 respectively. 226 Their creditors came from many places; in the case of Bernhard from Amsterdam, Bordeaux, Genoa, Mogador, Rostock, Köln, Leiden, London, Frankfurt, Paramaribo, Altona and Copenhagen, but no one from Marseille or Izmir figured on the list, suggesting that all matters between Offerman, Bernhard, Blanchenay and Chabeaud had been solved. ${ }^{227}$

Disputes brought before the Dutch consul in Izmir most often involved merchants. Dutch Levant trade did not rely on intermediaries on land alone but also required the involvement of maritime personnel. In Mediterranean ports, where European ships could spend months selling merchandise and trying to secure a return cargo, it was often the skipper who negotiated with Dutch and foreign firms to find merchandise for the voyage back to the United Provinces. It was a crucial responsibility, as time that was spent idling in port was costly, particularly as crews continued to receive their wages. ${ }^{228}$ Formally speaking, skippers and other maritime personnel were not part of the Dutch trading community of Izmir, but, upon arrival, they were obliged to take a national oath, with which they promised that the ship's manifests they had signed were truthful. ${ }^{229}$ When they were in port, the Dutch consul had jurisdiction over them and was expected to help them draft documents that normally required a notary. While not the most visible part of the commercial chain connecting Dutch cities with Izmir, they were a crucial element in that chain.

Much like how merchants could have quarrels, things could also go wrong between traders and seamen. Settling maritime disputes was a special category of consular adjudication. Since the middle of the seventeenth century, the courts in the United Provinces qualified to adjudicate maritime disputes in first instance were the Commissioners of Maritime Affairs. These were urban

226 For the institution of the Desolate Boedelskamer, see pp. 202-203. Bernhard's bankruptcy was his second, after an earlier bankruptcy in 1772 .

227 CAA, $\mathrm{N}^{\circ}{ }_{5} \mathrm{O}_{2}$ ('Archieven van de Commissarissen van de Desolate Boedelskamer'), $\mathrm{N}^{\circ} 3764$ (Offerman \& Engler), as well as $\mathrm{N}^{\circ} 3139$ and $\mathrm{N}^{\circ} 3536$ (both for Philip Ludwig Bernhard).

228 For Dutch shipping in the Mediterranean context and the involvement of skippers and seamen, see Vanneste, 'Sailing through the straits'.

229 Heeringa and Nanninga, Bronnen tot de geschiedenis, 2: pp. 214-215, 'Formulier van den eedt voor de schippers, stuurlieden, supracargos en andre, die eenich bewint ofte directie ontrent ' $t$ lossen of 't laeden van scheepen sijn hebbende, respective', 1676. This is similar to the national oath merchants had to take; see p. 57 . 
courts, and their verdicts could be appealed at higher provincial courts such as the Hof van Holland (see figure 5). ${ }^{230}$ Their jurisdiction covered conflicts involving sailors, skippers and freighters, without further specification of the origins of these men. The absence of any definition of geographical jurisdiction was logical, as most maritime disputes originated at sea or in a port where neither of the litigants was at home. It was easy to determine the consular jurisdiction in case of a maritime dispute between Dutch traders and sailors, but considering the frequent use foreign merchants made of Dutch shipping, there were obvious potential jurisdictional issues in case a dispute should arise.

In ports where there was a Dutch consul, Dutch skippers and sailors could go to a Dutch court, which they were entitled to as defendants according to the forum rei principle. There was no legislation that made a distinction between the consul's competence to adjudicate a dispute involving Dutch seafarers who happened to be in the city where the consul resided and a dispute involving Dutch merchants who lived in that city and thus fell under the consul's jurisdiction permanently. Intriguingly, regulations issued by the States General in 1658 covering consular responsibilities throughout the Mediterranean limited the fees consuls were allowed ask from skippers for the help given to them for their extra-ordinary needs (going beyond the drafting of notarial documents, for instance, which was a basic service). These needs included involvement in trials and adjudicating disputes. ${ }^{231}$

The adjudication of disputes that occurred on board a ship was not clearly defined in terms of jurisdiction. While, theoretically, forum rei could be chosen, leading to adjudication at the court of the defendant, such a court might be nowhere near the ship's nearest land location. This is perhaps why several early modern laws on maritime adjudication are not specific on jurisdiction in terms of geography but more so in terms of the people involved. The Instructien (Instructions) for the maritime court of Amsterdam specified that these were competent for conflicts between 'merchant and skipper, merchant and seaman, skipper and skipper, skipper and seaman, as also between merchant and pilot, freighters and freighters, ship owners and ship owners, as also skippers with their ship owners, in cases concerned with maritime navigation. ${ }^{232}$ The Rotterdam maritime court had issued the same phrasing,

230 See chapter two. For the earlier development of maritime law in the Low Countries, see De ruysscher, 'Maxims, principals and legal change'.

231 Cau, Groot placaet-boeck, 2: pp. 1343-1344, 'Extract uyt 't register der resolutien vande hoogh mogende heeren Staten Generael', 24/07/1658.

232 Instructien (1731), p. 4, '[...] tusschen koopman en schipper, tusschen koopman en bootsgezel, tusschen schipper en schipper, tusschen schipper en bootsgezel, item tusschen 
as well as England's Admiralty Court. ${ }^{233}$ No mention was made of a possible distinction between foreigners and Dutchmen or citizens of specific cities. Concerning jurisdiction, Louis XIV's influential Ordonnance de la marine from 1681 stated that 'the judges of the Admiralty will privately rule over all others, and between all persons of whichever quality they may be, even those who are privileged, Frenchmen and foreigners, both as plaintiffs and defendants, of all that concerns the construction, the tackle and gear, armament, provisioning and equipment, sale and tendering of ships. ${ }^{234}$ It is a particularly interesting statement as it not only suggests similar treatment at the court for Frenchmen and foreigners but also specifically went against the principle of forum rei by specifically stating that it would hear disputes between people regardless of their subject status. This has to do with the fact that during the Ancien Régime, two principles to organise legal jurisdiction co-existed: ratione personarum, meaning that jurisdiction is determined on the basis of the person, his or her legal status as subject; and ratione materiae, which determined jurisdiction on the basis of the matter - for instance a maritime dispute being adjudicated in a maritime court. ${ }^{235}$ According to Maria Fusaro, the range of maritime jurisdiction was debated and depended on local circumstances and accidents of navigation. Jurisdiction could, to a certain extent, be negotiated, and in some instances, skippers could influence the choice of court that would try them by steering their ships to specific ports. ${ }^{236}$

koopman en lootsman, mitsgaders tusschen inladers en inladers, reeders en reeders, als ook schippers met haar reeders, in zaaken de zeevaart aangaande [...]'.

233 See pp. 117-118; and Steckley, 'Merchants and the Admiralty Court', p. 137.

234 Ordonnance de la marine du mois d'aoust 1681. Commentée \& conferée avec les anciennes ordonnances, \& le droit ecrit: Avec les nouveaux reglemens concernans la marine (Paris, 1714), p. 15, 'Les juges de l'amirauté connaîtront privativement à tous autres, \& entre tous personnes de quelque qualité qu'elles soient, même privilégiées, François et etrangers, tant en demandant qu'en deffendant, de tout ce qui concerne, la construction, les agrez \& apparaux, armement, avictuaillement \& equipement, vente \& adjudication des vaisseaux'; for a more general discussion, see Bernard Allaire, 'Between Oléron and Colbert: The evolution of French maritime law until the seventeenth century', in Labour, law, and empire, pp. $79-99$.

235 The development of commercial law has often been considered a straightforward process from ratione personarum to ratione materiae, for instance in Umberto Santarelli, Mercanti e società tra mercanti (Torino, 1998), pp. 18-29; and Dave De ruysscher, Gedisciplineerde vrijheid, p. 41, but there are strong indications this was not the case. See Cerutti, Giustizia sommaria, pp. 28-29; and Fusaro, 'Politics of justice/politics of trade'.

236 Maria Fusaro argued that the specified final port in a contract written up for a specific journey could play a role in these considerations, but this did not prevent maritime disputes from being adjudicated in cities that had not been specified as final ports of call. Personal communication with Maria Fusaro, 29 April 2019. 
A good example is the 1743 dispute that arose between the Sicilian merchant Gasparo Marchetti and the Dutch skipper Cornelis Volkers. Volkers freighted his vessel, the Sofia en Catarina, in Trieste, and planned to sail to Messina and Livorno. On 14 June 1743 the ship arrived in Messina, where the plague was raging. According to the skipper and several of his crewmembers, the merchants to whom the merchandise was consigned did not want the goods to be unloaded because of the plague, but one of them, Gasparo Marchetti, declared that it was the skipper who had refused to unload because of the reigning chaos. ${ }^{237}$

In any case, a new charterparty was drafted in Messina in which it was specified that the goods should be unloaded in Livorno or elsewhere, but not in Messina. The charterparty was signed by a trader named Michele Panno and then endorsed to Marchetti, who had come aboard in Messina with his son and two servants, probably hoping to escape the plague. This was against all regulations, but Marchetti assured Volkers that he was taking full responsibility for it. On 25 June, the ship left Messina for Livorno, where they were refused entrance into the port as they were coming from a city stricken by the plague. A new pilot, also from Messina, came aboard in Livorno at the suggestion of Marchetti, and although a first attempt was made to sail to Marseille, the weather forced them elsewhere. As Marchetti was the freighter, he pretended to be in control of the voyage and wanted the ship to go to the Ambracian Gulf on the western coast of the Peloponnesus, but when the ship was near Stromboli, approaching the Strait of Messina, the crew got the feeling that Marchetti, a Sicilian, was planning to abandon the vessel and go ashore. ${ }^{238}$ The skipper then decided to set sail for Izmir, according to the skipper and crew with Marchetti's consent, but Marchetti declared later that he was 'violently taken by Captain Volkers to this city of Smyrna [Izmir], against the law of his contract.'. 239

237 NACs, $\mathrm{N}^{\circ} 316$ ('Alle de stukken rakende de zaken van capt. Cornelis Volkers van t fluijtschip de Soffia en Caterina, en sig. Gasparo Maria Marchetti Messinees adi ... stemb. tot 3 october 1743'), 'Verklaring van den capt Cornelis Volkers, zyn stuijrman en een matroos, wegens zijn vertrek van Messina en Livorno wegens de pest', Izmir, 13/o9/1743; 'Consulaet der zee vant fluijtschip de Sofia en Caterina capt Cornelis Volkers', Izmir, 13/og/1743; Declaratie [by crewmembers], [Izmir], [11/og/1743]; and NACs, $\mathrm{N}^{\circ} 316$, 'Protest van sig.r Gasparo Ma. Marchetti, teegen dheer Consul de Hochepied, en cap:to Cornelis volkers', Izmir, 02/10/1743.

238 NACs, $\mathrm{N}^{\circ} 316$, 'Verklaring van den capt Cornelis Volkers, zyn stuijrman en een matroos, wegens zijn vertrek van Messina en Livorno wegens de pest', Izmir, 13/og/1743.

239 NACS, $\mathrm{N}^{\circ} 316$, 'Eerste request van dheer Gasparo Ma. Marchetti', Izmir, [19/og/1743], '[...] esser stato violentem.te condotto $\mathrm{dl}$ cap Cornelis Wolkers 'n qsta città di smirne contro la leggi di suo contratto [...]'. 
The choice of Izmir is interesting, as the skipper justified it by considering it the safest place to protect his ship and the merchandise on board in case troubles should arise. After the events in Messina and Livorno, he was expecting difficulties. ${ }^{240}$ This claim was part of a statement skipper Volkers had drafted within two days after arriving in Izmir, which was co-signed by his helmsman and a sailor who understood Italian. The statement was drafted a week before Marchetti filed his petition at the Dutch consular court. The text of Volkers' statement clearly acknowledged that the skipper was well aware of the risks he had taken by accepting a change to the original freight contract, which included more traders than just Marchetti, and by continuing on the voyage after officials in Livorno had refused him entry - as Livorno had featured on the original charterparty. The skipper must have known which port cities in the Mediterranean had Dutch diplomatic representation and provided him with the possibility of defending himself before Dutch magistrates, which also explains the original choice to go to Marseille after Livorno.

Things might have been substantially more complicated in an Italian port, or in 'Chiarenza' (now known as Glarentza), an Ottoman port city south of the Ambracian Gulf (near Kyllini in present-day Greece), where Marchetti had first insisted on going. ${ }^{241}$ The whole discussion demonstrates that merchants and skippers were well aware of their possibilities for adjudication in different places, and the conscious practice of navigating to a particular city in the hopes of getting adjudicated there might be the maritime counterpart of the practice of forum shopping. In this case, Cornelis Volkers knew there were Dutch legal institutions in place that were designed to adjudicate maritime and commercial disputes, and he wanted to navigate to a place that had access to such institutions rather than being forced into adjudication by Italian or Ottoman judges. Volkers also knew that, if he arrived in a port city with a Dutch consul, there might be fellow skippers there who could be asked to draft a witness statement, and he countered Marchetti's claims by stating that 'the captains of my nation in this port can testify to my character, and my honourable habits.'.242

240 NACs, $\mathrm{N}^{\circ} 316$, 'Verklaring van den capt Cornelis Volkers, zyn stuijrman en een matroos, wegens zijn vertrek van Messina en Livorno wegens de pest', Izmir, 13/o9/1743.

241 NACS, $\mathrm{N}^{\circ} 316$, 'Sonder datum schrift van Sig:r Gasparo Ma marchettj messinees met zijn Eerste Req:t overgeleeverd, inhoúdende zijn pretenzie en verantwoordinge tegen Cap:to Cornelis volkers zyn gedrag op de reyze', S.l., S.d.

242 NACS, ${ }^{\circ} 316$, 'Request antwt van cap Cornelis Volkers, op dat van sr Gasparo M:a Marchetti', Izmir, $24 / 09 / 1743$, '[...] li cap.i di mia nazione in questo porto asistento possono testificare qualsia il mio carattere e quali li miei honorati costume [...]'. 
It is an interesting parallel to the importance merchants gave to reputation, although it is remarkable that, contrary to merchants, this skipper specifically referred to fellow nationals who were able to testify about his character. This might have to do with the fact that the skipper found himself physically distant from the place where he lived. He had an itinerant profession, while the merchants involved in eighteenth-century international trade were no longer physically moving about to conduct business but relied on a web of correspondents and agents. For them, reputation was an important instrument used to establish trust and assess the risks of engaging in business with a fellow trader who he might never see in person. For skippers, their activities were based more on physical encounters, lessening the need to develop some sort of usage that could validate behaviour through reputation. But in case of trouble, a skipper still wanted to prove that he was of a reliable character. There were only so many Dutch skippers sailing to Izmir, because Dutch navigation was specialised geographically, which meant that he must have known several of his Dutch colleagues in person. Considered this way, a skipper's recourse to fellow nationals is testimony to the importance of reputational mechanisms based on a shared occupation, in this case navigation to Izmir.

The fact that the Sofia en Catarina had come from a city where the plague was raging was an additional danger. It already had been refused entry in Livorno, something that could repeat itself elsewhere. Quarantine laws in the Ottoman Empire were non-existent - the Ottomans only adopted institutional reforms to battle the plague after 1800 - in spite of a similar scientific knowledge of the problem as the Europeans. ${ }^{243}$ This provided Volkers with a second good reason to sail to Izmir, and the Dutch skipper wrote that it had been his purpose to find public officials from whom he could obtain clean bills of health for himself and his crew as well as permission to continue his voyage without further problems. ${ }^{244}$ The problem was that Marchetti did not want to be in Izmir, but now that he was there, he wanted the goods consigned to him on board of Volker's ship to be unloaded immediately, while Volkers claimed he was not allowed to do so according to the terms of his contract.

As the dispute concerned contractual disputes as well as the complicated context of potential disease, the consul organised a meeting not only with the assessors but also with other Dutch merchants to ask their opinion. They

243 Birsen Bulmuş, Plague, quarantines and geopolitics in the Ottoman Empire (Edinburgh, 2012), pp. 39-40; see also Daniel Panzac, La peste dans l'empire Ottoman, 1700-1850 (Leuven, 1985).

244 NACs, $N^{\circ} 316$, 'Request antwt van cap Cornelis Volkers, op dat van sr Gasparo M:a Marchetti', Izmir, 24/o9/1743. 
declared the second charterparty, which was made with Panno and endorsed to Marchetti, as void and denied the Sicilian's request to unload, first of all because he could not prove all the goods had been consigned to him, and secondly because it would take a long time to unload - at a time when the plague was already raging in Istanbul and might well arrive in Izmir. Unloading increased the risk that Volkers would run out of time and would not receive the clean bills of health he needed to continue his voyage. Marchetti's claim harmed the interests of the other freighters and only seemed to serve himself, a clear violation of the merchants' style. The consul gave Volkers two days to obtain the documents he needed, after which he was free to continue his voyage 'as was customary according to sailor's style'. ${ }^{245}$ Similar to the multiple references to the merchants' style that were invoked to justify sentences concerning commercial disputes, the 'sailor's style' was equally used to suggest that there was a common way of doing things, generally accepted and understood by the involved parties, and by which they would have to behave themselves.

Not surprisingly, Marchetti protested this decision, and he filed his complaint with the consul of the Kingdom of the Two Sicilies in Izmir, Antonio Romiti. ${ }^{246}$ Marchetti protested but did not appeal, and this might have had to do with his difficulty deciding where to appeal. Maritime disputes did not necessarily follow forum rei because navigational issues might play a role. An appeal would be equally hard to follow. Marchetti should appeal before a Sicilian court, but the skipper against whom he wished to litigate would probably already be at sea by then. The Dutch consul allowed Volkers to leave within the next two days, and Marchetti felt that 'the road to appeal to a superior tribunal in this city was closed, and thus he protested not only against Volkers but also against the consul himself. ${ }^{247}$ It seems Marchetti attempted to keep the ship in port long enough for an official appeal to be filed, with the support of other merchants in Messina who were involved in the shipment. When the Dutch consul was informed of this, he filed a counter-protest in his own name. He felt that Marchetti had created the problem in the first place by illegally coming on board the ship in Messina, thereby endangering the whole crew. He also thought that Marchetti's legal challenge of the consular judge was

245 NACS, $\mathrm{N}^{\circ} 316$, 'Extract ùijt de notulen van de gehoudene bisoignes ter vergadering van haer hoog mog consul midsgaeders de koopluyden vande nederlandse natie', Izmir, 30/ o9/1743, '[...] zoo alz near zeemanstijl gebrúijkelijk [...]'.

246 NACs, $\mathrm{N}^{\circ} 316$, 'Protest van sig.r Gasparo Ma. Marchetti, teegen dheer Consul de Hochepied, en cap:to Cornelis Volkers', Izmir, o2/10/1743.

247 Ibid., '[...] onde vedendosi il medemo preclusa la strada in qsta piazza di poter ricorrere ad altro tribunale superiore $[\ldots]$ '. 
an anomaly that was unheard of, particularly considering the agitated state in which Marchetti had expressed his sentiments. ${ }^{248}$ The consul concluded by stating that the Dutch court did not owe Marchetti any explanation about its verdict, and he could appeal the verdict at another court in case he disagreed. His protest was therefore considered void and of no value, a decision that Daniel Alexander de Hochepied communicated to the consulate of the Kingdom of the Two Sicilies. ${ }^{249}$

Marchetti was thus free to appeal, but Volkers would have been long gone by then. In maritime disputes in which litigants of different territorial jurisdictions were involved, there was thus a potential clash of interests arising from the practical need for cooperation. Although de Hochepied had decided to free Volkers of any legal responsibility, he still had the option to keep him in port, allowing the plaintiff to file his appeal at the relevant (Sicilian) court. But the consul did not allow that option, perhaps because he was angry at Marchetti's behaviour or perhaps because he felt Dutch commercial interest was best served if Volkers was allowed to continue his journey without delay. This case brings to light a practical limitation when it came to the full exercise of all legal rights at all competent courts in the case of a maritime dispute when parties were often on the move, and it might even show the unwillingness of one court - the Dutch consular court - to cooperate with an appeal against its verdict at another, foreign, court. Particularly in litigation involving a plaintiff and defendant from separate jurisdictions, the execution of a sentence could be difficult. ${ }^{250}$ This is why the Dutch had issued a regulation stipulating that traders submitting themselves to court judgments had to consent beforehand to respect the sentence, and also why, particularly in cases between Dutch and non-Dutch, the possibilities of appeal were formally restricted. ${ }^{251} \mathrm{~A}$ proposal for a regulation of the legal powers of consuls and ambassadors as judges, first drafted in 1673 , contained an article specifying that, in appeals made against the sentence of a dispute between a Dutch national and a non-Dutch, either European or Ottoman, the condemned party had to pay a caution to the Dutch chancery to the amount of the sum determined in the sentence, guaranteeing the execution of the verdict should it be upheld at another court, which might

248 NACs, $\mathrm{N}^{\circ}{ }_{316}$, 'Contraprotest van haer hoog mog: consul op dat van Gasparo M:a Marchetti Messinees, rakende 't fluijtschip de Soffia x Caterine cap:t Cornelis Volkers', Izmir, o7/10/ 1743 .

249 Ibid.

250 See Calafat, 'La juridiction des consuls français', p. 16.

251 Heeringa and Nanninga, Bronnen tot de geschiedenis, 2: pp. 252-254, 'Resolutie der StatenGeneraal betreffende de rechtspraak in de Levant', 23/o2/1686. 
be far away. The condemned party might have left Izmir to never come back, rendering execution of a sentence impossible without a caution..$^{252}$

This proposal never became a formal regulation, but it shows nonetheless that intercultural litigation was a difficult balancing act between the custom of merchants on the one hand and the duty and jurisdiction of consular judges on the other. The success of trade depended to an important extent on the degree of acceptance amidst traders, sailors and judges of customs and procedures. Marchetti's protest directly against the consul was a violation of such acceptance, and it was an infraction of the legal custom that had developed between the different European trading nations in the Levant. Marchetti had the option to appeal, but he was not to question the legitimacy of the Dutch consul as judge, particularly because he was considered to be responsible for the whole situation. From this point of view, it is perfectly explainable that the consul reacted so mercilessly to Marchetti's protest, even if, from a practical point of view, the Sicilian trader had a point: how could he possibly expect a successful appeal against a skipper who was sailing across the Mediterranean to other unknown ports? Marchetti's fate is not known, but the Dutch must have forgotten his personal attack on the consul. In 1774 he reappears in official documentation from the States of Holland as temporary Dutch consul in Messina. ${ }^{253}$

252 Ibid., pp. 187-204, 'Reglement voor den resident tot Constantinopelen, consul tot Smirna, ende Nederlantsche natie in de Levant residerende respective, sooals hetselve bij de heeren Directeuren van den Levantschen handel aen H.H.M. is overgegeven, en bij deselve weder aen den Consul van Dam gesonden', 1675, particularly on pp. 199-200.

253 Resolutien van de heeren Staaten van Holland en Westvriesland in haar edele groot mog.vergadering genoomen in den jaare 1774, pp. 494-495, 'Missive van G.M. Marchetti de Gaspere over de difficulteit in het waarneemen der saaken van de Hollandsche natie als interims consul, om dat vasal was van de Koning van Napels', 15/07/1774. 